\title{
Glycosylation pattern of brush border-associated glycoproteins in enterocyte-like cells: involvement of complex-type $\mathrm{N}$-glycans in apical trafficking
}

\author{
Willy Morelle1, Laurence Stechly"2,3, Sabine \\ André $^{4}$, Isabelle Van Seuningen ${ }^{2}$, Nicole \\ Porchet $^{2,3}$, Hans-Joachim Gabius ${ }^{4}$, Jean-Claude \\ Michalski ${ }^{1}$ and Guillemette Huet ${ }^{2,3, *}$ \\ ${ }^{1}$ UMR CNRS 8576, Unité de Glycobiologie Structurale \\ et Fonctionnelle, IFR 147, F-59655 Villeneuve d'Ascq, \\ France \\ ${ }^{2}$ Centre de Recherche Jean-Pierre Aubert, INSERM \\ U837, CHRU, F-59045 Lille cedex, France \\ ${ }^{3}$ Centre de Biologie Pathologie Pierre Degand, CHRU, \\ F-59037 Lille cedex, France \\ ${ }^{4}$ Institute of Physiological Chemistry, Faculty of \\ Veterinary Medicine, Ludwig Maximililans University \\ Munich, D-80539 Munich, Germany \\ ${ }^{*}$ Corresponding author \\ e-mail: guillemette.huet@inserm.fr
}

\begin{abstract}
We have previously reported that galectin-4, a tandem repeat-type galectin, regulates the raft-dependent delivery of glycoproteins to the apical brush border membrane of enterocyte-like HT-29 cells. $N$-Acetyllactosamine-containing glycans, known as galectin ligands, were found enriched in detergent-resistant membranes. Here, we analyzed the potential contribution of $N$ - and/ or O-glycans in this mechanism. Structural studies were carried out on the brush border membrane-enriched fraction using matrix-assisted laser desorption/ionization time-of-flight mass spectrometry (MALDI-TOF-MS) and nano-ESI-QTOF-MS/MS. The pattern of $N$-glycans was very heterogeneous, with the presence of high mannoseand hybrid-type glycans as well as a multitude of complex-type glycans. In contrast, the pattern of O-glycans was very simple with the presence of two major core type $1 \mathrm{O}$-glycans, sialylated and bisialylated T-antigen structures [Neu5Ac $\alpha 2-3 \mathrm{Gal} \beta 1-3 \mathrm{GalNAc-ol}$ and Neu5Ac $\alpha 2-$ 3Gal $\beta 1-3($ Neu5Ac $\alpha 2-6)$ GalNAc-ol]. Thus, $N$-glycans rather than $\mathrm{O}$-glycans contain the $\mathrm{N}$-acetyllactosamine recognition signals for the lipid raft-based galectin-4-dependent apical delivery. In the presence of 1-deoxymannojirimycin, a drug which inhibits the generation of hybrid-type or complex type $N$-glycans, the extensively O-glycosylated mucin-like MUC1 glycoprotein was not delivered to the apical brush border but accumulated inside the cells. Altogether, our data demonstrate the crucial role of complex $\mathrm{N}$-glycans in the galectin-4-dependent delivery of glycoproteins to the apical brush border membrane of enterocytic HT-29 cells.
\end{abstract}

Keywords: brush border; detergent-resistant membrane (DRM); galectin-4; glycosphingolipids; $N$-glycans; O-glycans.

\section{Introduction}

The surface of epithelial cells is composed of apical and basolateral domains with distinct structure and function. The basolateral surface contains adhesion molecules and receptors while the apical surface expresses the markers of cellular differentiation. In intestinal cells, the apical surface forms a brush border of microvilli containing the proteins involved in intestinal digestion and uptake of nutriments. This asymmetric structure of epithelial cells implies a polarized vesicular trafficking of proteins and lipids to the apical and basolateral membrane regions (Mostov et al., 2000). Polarized protein targeting is based on apical and basolateral sorting signals, which guide the incorporation of proteins into distinct vesicles that then move specifically to the apical or basolateral membrane. Signals for basolateral targeting are encoded by tyrosine or dileucine motifs localized in the cytoplasmic domain of proteins (Matter and Mellman, 1994). These sequences are recognized by heterotrimeric adaptor complexes which then mediate the routing to the basolateral membrane (Nakatsu and Ohno, 2007). Sorting of proteins toward the apical membrane seems to be more diversified than basolateral targeting because various apical sorting signals have been found in extracellular, transmembrane or cytoplasmic domains of respective proteins (Schuck and Simons, 2004). The apical delivery can also involve the recruitment of apical glycoproteins into lipid rafts, which are membrane microdomains enriched in cholesterol and sphingolipids (Simons and Van Meer, 1988; Brown and Rose, 1992; Simons and Ikonen, 1997).

In view of the concept of the sugar code, ascribing high-density information storage to glycan chains of cellular glycoconjugates (Gabius et al., 2004; Gabius, 2008, 2009; André et al., 2009), it appears likely that $N$ - and $O$ glycans can embody sorting signals. The role of $N$ - and/ or O-glycans in the apical targeting of proteins was documented by several studies carried out in polarized Madin-Darby canine kidney cells or Caco-2 or HT-29 human intestinal cells. Deletion of $\mathrm{N}$ - and/or mucin-type $O$-glycosylation sites resulted in missorting of apical glycoproteins to the basolateral surface, whereas addition of $N$-glycosylation sites targeted the proteins to the apical surface (Scheiffele et al., 1995; Yeaman et al., 1997; Gut et al., 1998; Benting et al., 1999; Jacob et al., 2000; Pang et al., 2004). Several studies were also carried out with different inhibitors of glycosylation: tunicamycin, which blocks the transfer of $\mathrm{Glc}_{3} \mathrm{Man}_{9} \mathrm{GlCNAc}_{2}$ from 
dolichol to Asn, 1-deoxymannojirimycin or swainsonine which inhibit the trimming by $\alpha$-mannosidases, and GalNAc-O-bn, which inhibits the elongation of $O$-glycans (Gut et al., 1998; Huet et al., 1998; Naim et al., 1999; Alfalah et al., 2002; Vagin et al., 2004; Delacour et al., 2005).

Our previous work showed the crucial role of glycosylation in the apical secretion of mucins and the apical targeting of membrane proteins in mucus-secreting or enterocytic HT-29 cells (Hennebicq-Reig et al., 1998; Huet et al., 1998). Treatment of polarized HT-29 colon carcinoma cells by the inhibitor of glycosylation (1-benzyl-2-acetamido-2-deoxy- $\alpha$-D-galactopyranoside; GalNAc $\alpha-O-b n)$ induced a failure to deliver membrane or secreted apical glycoproteins and their abnormal storage inside the cells. Initially, this drug was considered to inhibit exclusively the elongation of the primer-like $\mathrm{N}$-acetylgalactosamine $\mathrm{O}$-linked to a serine or threonine residue in a competitive manner. However, we and others showed that this inhibitor was extensively converted into the disaccharide derivative Gal-GalNAc-O-bn inside the cells and that the resulting effect of GalNAc-O-bn treatment was instead an inhibition of the terminal substitution of galactose residues (Huang et al., 1992; Delannoy et al., 1996). In HT-29 cells, the major effect of GalNAc$O$-bn on the biosynthesis of $O$-glycans was an inhibition of the sialylation of the core 1 sequence Gal $\beta 1-$ 3GalNAc-R by the $\alpha 2,3$ sialyltransferase ST3Gal I (Delannoy et al., 1996; Huet et al., 1998). However, in addition to the effect of GalNAc-O-bn on the glycosylation of glycoproteins, we found that this compound markedly inhibited the biosynthesis of galactosylceramides and sulfated glycosphingolipids in HT-29 cells, due to the mobilization of the substrate UDP-Gal for the production of metabolites of GalNAc-O-bn (Zanetta et al., 2000; Delacour et al., 2005). Having described evidence for a role of glycans in sorting and trafficking, we investigated the identification of a putative protein-carbohydrate recognition system, i.e., to endogenous lectins, especially with specificity to substituted $\beta$-galactosides, such as the galectins (Gabius, 2006, 2008).

The research of a putative lectin receptor involved in the apical delivery in differentiated HT-29 cells brought to evidence galectin-4, a lectin expressed in the gastrointestinal tract of mammals (Delacour et al., 2005). This galectin is composed of a tandem repeat-type display of two carbohydrate recognition domains suited for potent cross-linking as probed by glycocluster reactivity (André et al., 2008). Silencing of galectin-4 expression using RNAi inhibited apical transport in the same way as previously shown to occur by GalNAc-O-bn treatment in HT29 cells (Delacour et al., 2005). Moreover, we have demonstrated that galectin-4 directly regulates the lipid raft-dependent delivery of apical glycoproteins in these cells. Galectin-4 was first identified as a major constituent of detergent-resistant membranes (DRMs) having a high affinity for glycosphingolipids, which are typical lipid components of DRMs (Delacour et al., 2005). Galectin-4 was then shown to be a critical factor involved in the recruitment of apical glycoproteins within DRMs (Stechly et al., 2009).

The glycan analysis of DRMs in comparison to the detergent soluble membrane fraction showed that DRMs were enriched in a series of complex type $\mathrm{N}$-glycans containing the $N$-acetyllactosamine sequence Gal $\beta 1-$ $4 \mathrm{GlcNAc}$, which is a basic unit recognized by galectins, for human galectin- 4 with $\Delta \mathrm{G}=4.8 \mathrm{kcal} / \mathrm{mol}$ (at $27^{\circ} \mathrm{C}$ ) as free disaccharide and $\Delta \mathrm{G}=7.34 .8 \mathrm{kcal} / \mathrm{mol}$ when presented in the complex type $\mathrm{N}$-glycans of asialofetuin (Dam et al., 2005). The purpose of this work was to analyze the potential contribution of $\mathrm{N}$ - and/or O-glycans in the regulation of the delivery of membrane proteins to the apical brush border membrane of HT-29 5M12 cells.

\section{Results}

\section{Analysis of the cellular distribution of glycan epitopes by confocal microscopy}

The distribution of glycan epitopes was analyzed in polarized enterocytic HT-29 5M12 cells using a confocal microscopy approach (Figure 1). The mannose-specific concanavalin $\mathrm{A}$ (ConA) lectin showed a strong reactivity at both apical and basolateral surface. In contrast, with the wheat germ agglutinin (WGA), which binds to $N$-acetylglucosamine, and the Maackia amurensis agglutinin (MAA) which reacts with NeuAc $\alpha 2-3 \mathrm{Gal}-R$, only the apical surface was labeled. Labeling with an anti-Lewis ${ }^{-x}$ antibody, which reacts with the Gal $\beta 1-4$ (Fuc $\alpha 1-3)$ GlcNAc epitope, mostly stained the apical surface and also subapical compartments (Figure 2). Altogether, these data clearly showed that the apical surface was enriched in complex type $\mathrm{N}$-glycans in comparison to the basolateral membrane. We have previously reported that inhibition of galectin-4 expression in HT-29 5M12 cells, by using a retrovirus-mediated RNA interference, abrogated apical targeting of brush border glycoproteins (Delacour et al., 2005). When the analyses with these lectins were carried out on galectin-4-knockdown (KD) HT$295 \mathrm{M} 12$ cells, the apical labeling disappeared and an intracellular labeling appeared, consistent with the perturbation of the apical delivery of glycoproteins and their abnormal intracellular accumulation in galectin-4-KD cells.

\section{Structural analysis of glycans present in the brush border-enriched membrane fraction}

Glycoproteins of the brush border membrane-enriched fraction were reduced/carboxyamidomethylated and digested with trypsin to facilitate deglycosylation with peptide $N$-glycosidase F (PNGase F). The released $N$ glycans were separated from peptides and glycopeptides on a C18 Sep-Pak (Waters Ltd., Saint-Quentin-enYvelines, France), and their methylated derivatives were characterized by matrix-assisted laser desorption/ionization time-of-flight mass spectrometry (MALDI-TOFMS) before and after sequential exoglycosidase digestions, by nano-ESI-QTOF-MS/MS, and by linkage analysis. These experiments were also supplemented by MALDI-TOF-MS of the products of hydrofluoric acid hydrolysis. O-Glycans were released by reductive elimination, permethylated, purified on a Sep-Pak cartridge, and characterized by MALDI-TOF-MS. 


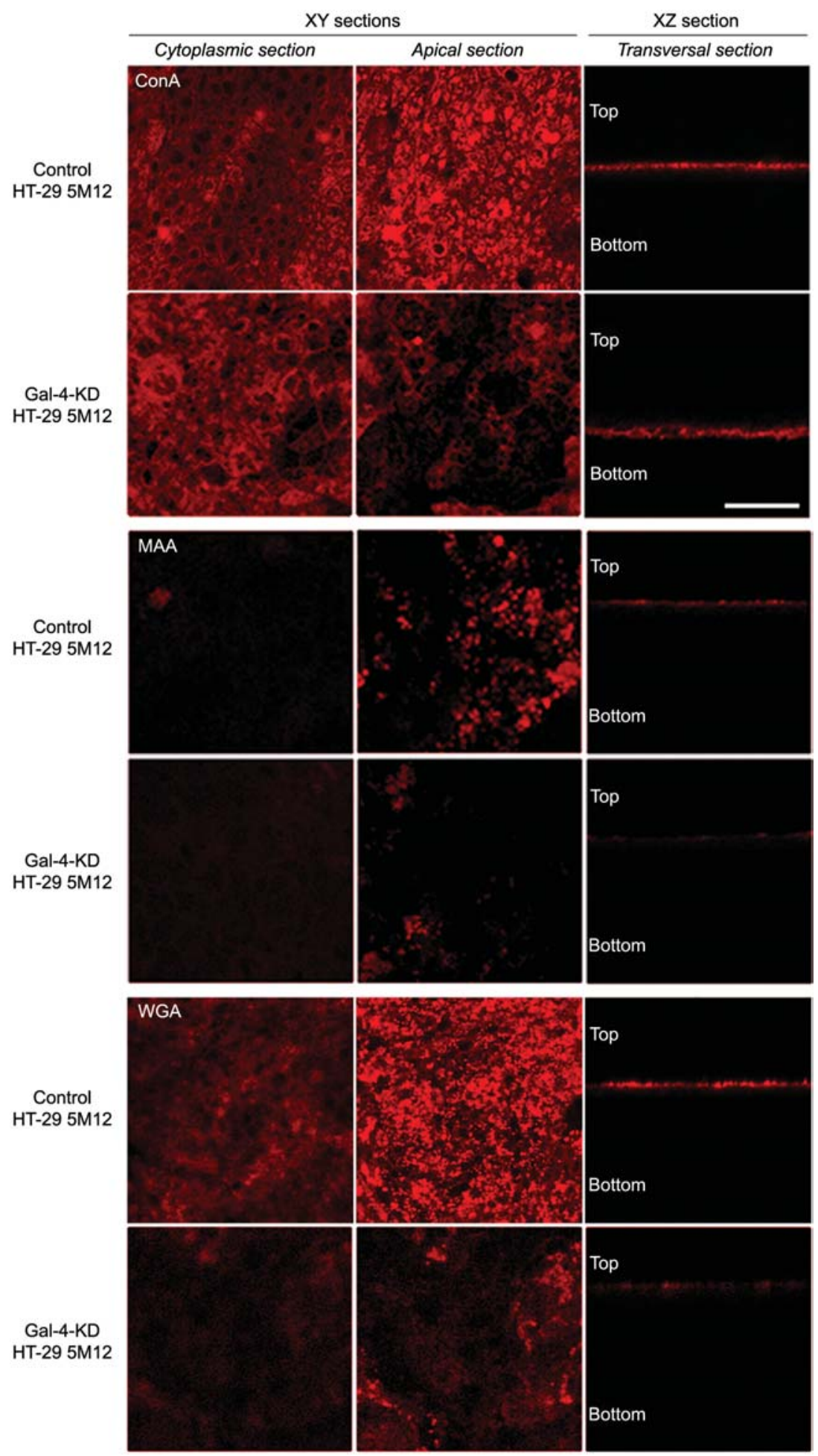

Figure 1 Analysis of the distribution of glycan epitopes in control HT-29 5M12 and galectin-4-KD HT-29 5M12 cells by confocal microscopy using fluorescent lectins.

In control cells, the mannose-specific lectin ConA showed a strong reactivity at both apical and basolateral surface. The WGA lectin, which binds to $N$-acetylglucosamine and the MAA lectin, which reacts with NeuAc $\alpha 2-3 \mathrm{Gal}-\mathrm{R}$ terminal sequence, showed a high staining at the apical surface. In contrast, in galectin-4-KD cells, the apical staining strongly decreased and an intracellular labeling appeared. Scale bar: $20 \mu \mathrm{m}$.

MALDI-TOF-MS analysis of $\mathbf{N}$-glycans The data from the MALDI-TOF-MS analysis of the permethylated PNGase F-released glycans are shown in Figure 3 and summarized in Table 1. The spectrum indicates that $N$ glycans have compositions consistent with high mannose-type structures $\left(\mathrm{Hex}_{5-9} \mathrm{HexNAc}_{2}\right)$ and complex/ hybrid-type glycans (NeuAc$\left.{ }_{0-3} \mathrm{Fuc}_{0-3} \mathrm{Hex}_{3-8} \mathrm{HexNAc}_{3-9}\right)$. In addition to the high mannose-type glycans Man $_{5}$ GlcNAc $_{2}-\mathrm{Man}_{9} \mathrm{GlcNAc}_{2}$ (m/z 1580-2396), a large number of different complex type $N$-glycans were detected with the following characteristics: (i) several complex type $N$ glycans have compositions consistent with bisected 


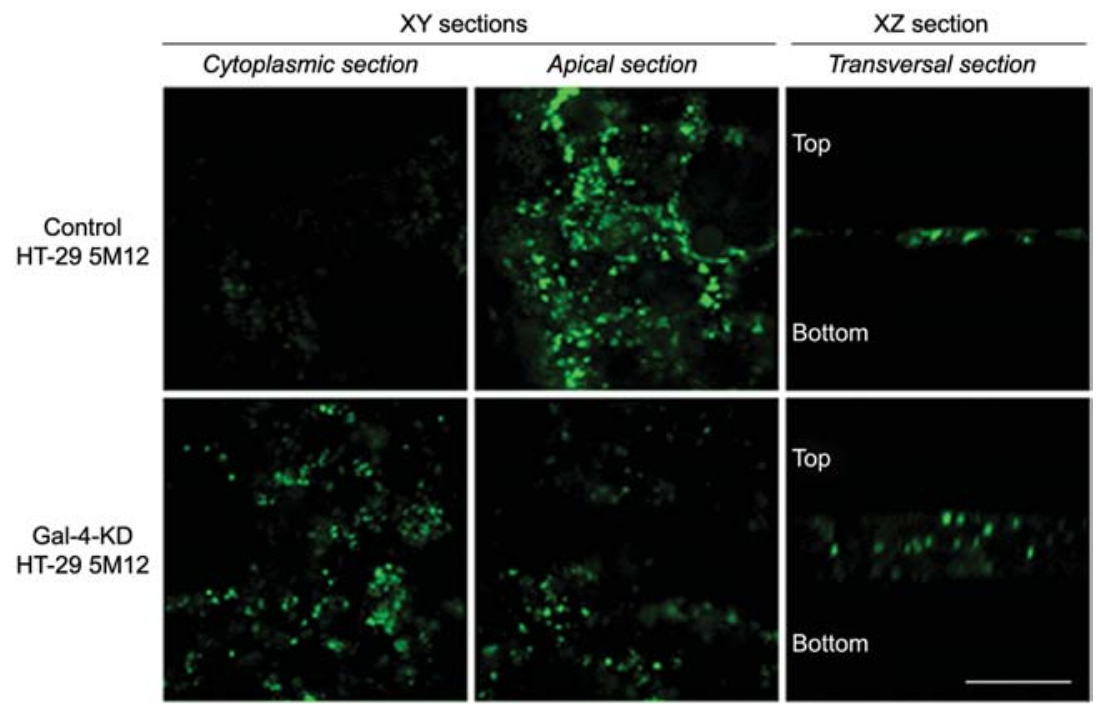

Figure 2 Analysis of the distribution of the Lewis-x epitope in control HT-29 $5 \mathrm{M} 12$ and galectin-4-KD HT-29 5M12 cells using confocal microscopy.

In control cells, the anti-Lewis-x antibody mostly stained the apical surface and subapical region. The apical labeling strongly decreased in galectin-4-KD cells, and an intracellular labeling appeared. Scale bar: $20 \mu \mathrm{m}$.

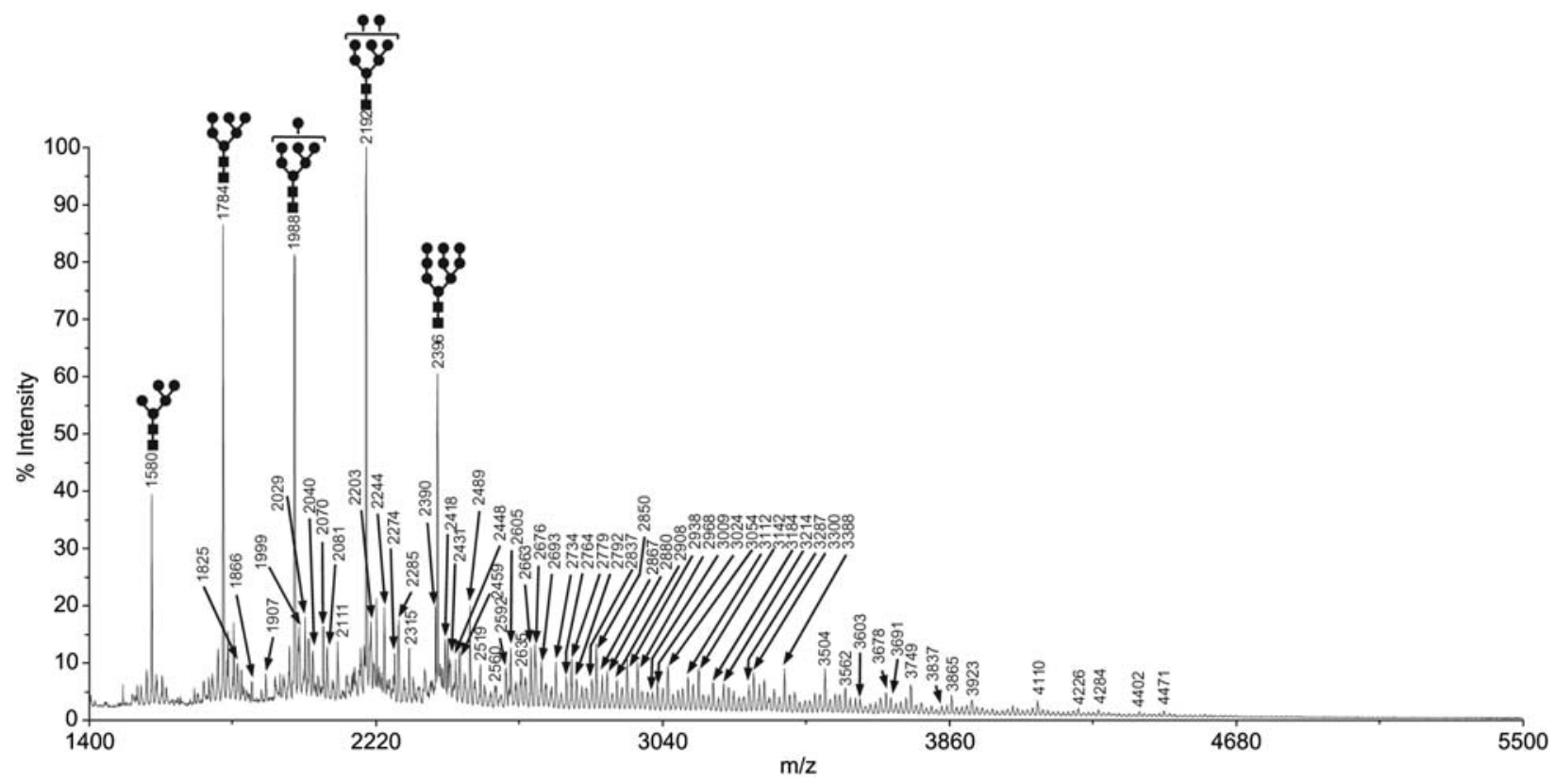

Figure 3 MALDI-TOF mass spectrum of permethylated $\mathrm{N}$-glycans from brush border-enriched membrane.

$\mathrm{N}$-Glycans were released by digestion with PNGase F, permethylated, and subjected to Sep-Pak clean-up. The permethylated derivatives were then analyzed by MALDI-TOF-MS in the positive ion reflective mode as $[\mathrm{M}+\mathrm{Na}]^{+}$. Only the structures of the major $\mathrm{N}$ glycans are given. Galactose (open circles), mannose (closed circles), GlcNAc (closed squares), GalNAc (open squares), fucose (open triangles), NeuAc (closed diamonds). The compositional assignment of the major signals is listed in Table 1.

structures $(\mathrm{m} / \mathrm{z} 1907,2081,2285,2315,2489,2663$, 2676, 2837, 2850, 3024); (ii) minor complex type N-glycans have compositions consistent with poly- $N$-acetyllactosamine extensions ( $\mathrm{m} / \mathrm{z}$ 3663, 3837, 3953, 4011, 4041, 4185, 4215, 4286, 4314, 4402,4460); (iii) several complex type $\mathrm{N}$-glycans $(\mathrm{m} / \mathrm{z} 2418,2592,2663,2779$, 2837, 2867, 2908, 3024, 3112, 3228, 3269, 3287, 3317, $3358,3403,3474,3491,3562,3590,3678,3719,3764$, $3923,4011,4185,4215,4284,4460)$ have compositions consistent with fucose moieties being present both on the core and on the antennae, and (iv) most of the com- plex type $\mathrm{N}$-glycans have compositions consistent with sialylated structures.

Linkage analysis of PNGase F-released glycans Linkage analysis on the PNGase F-released $N$-glycans yielded the data shown in Table 2. Several conclusions can be drawn from these data: (i) the presence of 3,6linked Man and 4-linked GlcNAc is in accordance with them being essential constituents of the core of $N$-glycans; (ii) terminal mannose is in accordance with the presence of high mannose-type structures and less 
Table 1 Assignments of molecular $[\mathrm{M}+\mathrm{Na}]^{+}$ions observed in the MALDI spectrum of permethylated $N$-glycans.

\begin{tabular}{|c|c|c|c|}
\hline $\begin{array}{l}\text { Signal } \\
(\mathrm{m} / \mathrm{z})\end{array}$ & Assignment & $\begin{array}{c}\text { Signal } \\
(\mathrm{m} / \mathrm{z})\end{array}$ & Assignment \\
\hline 1580 & $\mathrm{Hex}_{5} \mathrm{HexNAc}_{2}+\mathrm{Na}^{+}$ & 2880 & $\mathrm{NeuAc}_{1} \mathrm{Hex}_{6} \mathrm{HexNAc}_{5}+\mathrm{Na}^{+}$ \\
\hline 1784 & $\mathrm{Hex}_{6} \mathrm{HexNAc}_{2}+\mathrm{Na}^{+}$ & 2908 & $\mathrm{Hex}_{5} \mathrm{HexNAc}_{6} \mathrm{dHex}_{2}+\mathrm{Na}^{+}$ \\
\hline 1825 & $\mathrm{Hex}_{5} \mathrm{HexNAc}_{3}+\mathrm{Na}^{+}$ & 2921 & $\mathrm{NeuAc}_{1} \mathrm{Hex}_{5} \mathrm{HexNAc}_{6}+\mathrm{Na}^{+}$ \\
\hline 1866 & $\mathrm{Hex}_{4} \mathrm{HexNAc}_{4}+\mathrm{Na}^{+}$ & 2938 & $\mathrm{Hex}_{6} \mathrm{HexNAc}_{6} \mathrm{dHex}_{1}+\mathrm{Na}^{+}$ \\
\hline 1907 & $\mathrm{Hex}_{3} \mathrm{HexNAc}_{5}+\mathrm{Na}^{+}$ & 2968 & $\mathrm{Hex}_{7} \mathrm{HexNAc}_{6}+\mathrm{Na}^{+}$ \\
\hline 1988 & $\mathrm{Hex}_{7} \mathrm{HexNAc}_{2}+\mathrm{Na}^{+}$ & 3009 & $\mathrm{Hex}_{6} \mathrm{HexNAc}_{7}+\mathrm{Na}^{+}$ \\
\hline 1999 & $\mathrm{Hex}_{5} \mathrm{HexNAc}_{3} \mathrm{dHex}_{1}+\mathrm{Na}^{+}$ & 3024 & $\mathrm{NeuAc}_{1} \mathrm{Hex}_{5} \mathrm{HexNAc}_{5} \mathrm{dHex}_{2}+\mathrm{Na}^{+}$ \\
\hline 2029 & $\mathrm{Hex}_{6} \mathrm{HexNAc}_{3}+\mathrm{Na}^{+}$ & 3054 & $\mathrm{NeuAc}_{1} \mathrm{Hex}_{6} \mathrm{HexNAc}_{5} \mathrm{dHex}_{1}+\mathrm{Na}^{+}$ \\
\hline 2040 & $\mathrm{Hex}_{4} \mathrm{HexNAc}_{4} \mathrm{dHex}_{1}+\mathrm{Na}^{+}$ & 3095 & $\mathrm{NeuAc}_{1} \mathrm{Hex}_{5} \mathrm{HexNAc}_{6} \mathrm{dHex}_{1}+\mathrm{Na}^{+}$ \\
\hline 2070 & $\mathrm{Hex}_{5} \mathrm{HexNAc}_{4}+\mathrm{Na}^{+}$ & 3112 & $\mathrm{Hex}_{6} \mathrm{HexNAc}_{6} \mathrm{dHex}_{2}+\mathrm{Na}^{+}$ \\
\hline 2081 & $\mathrm{Hex}_{3} \mathrm{HexNAc}_{5} \mathrm{dHex}_{1}+\mathrm{Na}^{+}$ & 3125 & $\mathrm{NeuAc}_{1} \mathrm{Hex}_{6} \mathrm{HexNAc}_{6}+\mathrm{Na}^{+}$ \\
\hline 2111 & $\mathrm{Hex}_{4} \mathrm{HexNAc}_{5}+\mathrm{Na}^{+}$ & 3142 & $\mathrm{Hex}_{7} \mathrm{HexNAc}_{6} \mathrm{dHex}_{1}+\mathrm{Na}^{+}$ \\
\hline 2192 & $\mathrm{Hex}_{8} \mathrm{HexNAc}_{2}+\mathrm{Na}^{+}$ & 3184 & $\mathrm{Hex}_{6} \mathrm{HexNAc}_{7} \mathrm{dHex}_{1}+\mathrm{Na}^{+}$ \\
\hline 2203 & $\mathrm{Hex}_{6} \mathrm{HexNAc}_{3} \mathrm{dHex}_{1}+\mathrm{Na}^{+}$ & 3214 & $\mathrm{Hex}_{7} \mathrm{HexNAc}_{7}+\mathrm{Na}^{+}$ \\
\hline 2244 & $\mathrm{Hex}_{5} \mathrm{HexNAc}_{4} \mathrm{dHex}_{1}+\mathrm{Na}^{+}$ & 3228 & $\mathrm{NeuAc}_{1} \mathrm{Hex}_{6} \mathrm{HexNAc}_{5} \mathrm{dHex}_{2}+\mathrm{Na}^{+}$ \\
\hline 2274 & $\mathrm{Hex}_{6} \mathrm{HexNAc}_{4}+\mathrm{Na}^{+}$ & 3242 & $\mathrm{NeuAc}_{2} \mathrm{Hex}_{6} \mathrm{HexNAc}_{5}+\mathrm{Na}^{+}$ \\
\hline 2285 & $\mathrm{Hex}_{4} \mathrm{HexNAc}_{5} \mathrm{dHex}_{1}+\mathrm{Na}^{+}$ & 3269 & $\mathrm{NeuAc}_{1} \mathrm{Hex}_{5} \mathrm{HexNAc}_{6} \mathrm{dHex}_{2}+\mathrm{Na}^{+}$ \\
\hline 2315 & $\mathrm{Hex}_{5} \mathrm{HexNAc}_{5}+\mathrm{Na}^{+}$ & 3287 & $\mathrm{Hex}_{6} \mathrm{HexNAc}_{6} \mathrm{dHex}_{3}+\mathrm{Na}^{+}$ \\
\hline 2390 & $\mathrm{NeuAc}_{1} \mathrm{Hex}_{6} \mathrm{HexNAc}_{3}+\mathrm{Na}^{+}$ & 3300 & $\mathrm{NeuAc}_{1} \mathrm{Hex}_{6} \mathrm{HexNAc}_{6} \mathrm{dHex}_{1}+\mathrm{Na}^{+}$ \\
\hline 2396 & $\mathrm{Hex}_{9} \mathrm{HexNAc}_{2}+\mathrm{Na}^{+}$ & 3317 & $\mathrm{Hex}_{7} \mathrm{HexNAc}_{6} \mathrm{dHex}_{2}+\mathrm{Na}^{+}$ \\
\hline 2418 & $\mathrm{Hex}_{5} \mathrm{HexNAc}_{4} \mathrm{dHex}_{2}+\mathrm{Na}^{+}$ & 3330 & $\mathrm{NeuAc}_{1} \mathrm{Hex}_{7} \mathrm{HexNAc}_{6}+\mathrm{Na}^{+}$ \\
\hline 2431 & $\mathrm{NeuAc}_{1} \mathrm{Hex}_{5} \mathrm{HexNAc}_{4}+\mathrm{Na}^{+}$ & 3358 & $\mathrm{Hex}_{6} \mathrm{HexNAc}_{7} \mathrm{dHex}_{2}+\mathrm{Na}^{+}$ \\
\hline 2448 & $\mathrm{Hex}_{6} \mathrm{HexNAc}_{4} \mathrm{dHex}_{1}+\mathrm{Na}^{+}$ & 3388 & $\mathrm{Hex}_{7} \mathrm{HexNAc}_{7} \mathrm{dHex}_{1}+\mathrm{Na}^{+}$ \\
\hline 2489 & $\mathrm{Hex}_{5} \mathrm{HexNAc}_{5} \mathrm{dHex}_{1}+\mathrm{Na}^{+}$ & 3403 & $\mathrm{NeuAc}_{1} \mathrm{Hex}_{6} \mathrm{HexNAc}_{5} \mathrm{dHex}_{3}+\mathrm{Na}^{+}$ \\
\hline 2519 & $\mathrm{Hex}_{6} \mathrm{HexNAc}_{5}+\mathrm{Na}^{+}$ & 3416 & $\mathrm{NeuAc}_{2} \mathrm{Hex}_{6} \mathrm{HexNAc}_{5} \mathrm{dHex}_{1}+\mathrm{Na}^{+}$ \\
\hline 2560 & $\mathrm{Hex}_{5} \mathrm{HexNAc}_{6}+\mathrm{Na}^{+}$ & 3474 & $\mathrm{NeuAc}_{1} \mathrm{Hex}_{6} \mathrm{HexNAc}_{6} \mathrm{dHex}_{2}+\mathrm{Na}^{+}$ \\
\hline 2592 & $\mathrm{Hex}_{5} \mathrm{HexNAc}_{4} \mathrm{dHex}_{3}+\mathrm{Na}^{+}$ & 3491 & $\mathrm{Hex}_{7} \mathrm{HexNAc}_{6} \mathrm{dHex}_{3}+\mathrm{Na}^{+}$ \\
\hline 2605 & $\mathrm{NeuAc}_{1} \mathrm{Hex}_{5} \mathrm{HexNAc}_{4} \mathrm{dHex}_{1}+\mathrm{Na}^{+}$ & 3504 & $\mathrm{NeuAc}_{1} \mathrm{Hex}_{7} \mathrm{HexNAc}_{6} \mathrm{dHex}_{1}+\mathrm{Na}^{+}$ \\
\hline 2635 & $\mathrm{NeuAc}_{1} \mathrm{Hex}_{6} \mathrm{HexNAc}_{4}+\mathrm{Na}^{+}$ & 3545 & $\mathrm{NeuAc}_{1} \mathrm{Hex}_{6} \mathrm{HexNAc}_{7} \mathrm{dHex}_{1}+\mathrm{Na}^{+}$ \\
\hline 2663 & $\mathrm{Hex}_{5} \mathrm{HexNAc}_{5} \mathrm{dHex}_{2}+\mathrm{Na}^{+}$ & 3562 & $\mathrm{Hex}_{7} \mathrm{HexNAc}_{7} \mathrm{dHex}_{2}+\mathrm{Na}^{+}$ \\
\hline 2676 & $\mathrm{NeuAc}_{1} \mathrm{Hex}_{5} \mathrm{HexNAc}_{5}+\mathrm{Na}^{+}$ & 3575 & $\mathrm{NeuAc}_{1} \mathrm{Hex}_{7} \mathrm{HexNAc}_{7}+\mathrm{Na}^{+}$ \\
\hline 2693 & $\mathrm{Hex}_{6} \mathrm{HexNAc}_{5} \mathrm{dHex}_{1}+\mathrm{Na}^{+}$ & 3590 & $\mathrm{NeuAc}_{2} \mathrm{Hex}_{6} \mathrm{HexNAc}_{5} \mathrm{dHex}_{2}+\mathrm{Na}^{+}$ \\
\hline 2734 & $\mathrm{Hex}_{5} \mathrm{HexNAc}_{6} \mathrm{dHex}_{1}+\mathrm{Na}^{+}$ & 3603 & $\mathrm{NeuAc}_{3} \mathrm{Hex}_{6} \mathrm{HexNAc}_{5}+\mathrm{Na}^{+}$ \\
\hline 2764 & $\mathrm{Hex}_{6} \mathrm{HexNAc}_{6}+\mathrm{Na}^{+}$ & 3663 & $\mathrm{Hex}_{8} \mathrm{HexNAC}_{8}+\mathrm{Na}^{+}$ \\
\hline 2779 & $\mathrm{NeuAc}_{1} \mathrm{Hex}_{5} \mathrm{HexNAc}_{4} \mathrm{dHex}_{2}+\mathrm{Na}^{+}$ & 3678 & $\mathrm{NeuAc}_{1} \mathrm{Hex}_{7} \mathrm{HexNAc}_{6} \mathrm{dHex}_{2}+\mathrm{Na}^{+}$ \\
\hline 2792 & $\mathrm{NeuAc}_{2} \mathrm{Hex}_{5} \mathrm{HexNAc}_{4}+\mathrm{Na}^{+}$ & 3691 & $\mathrm{NeuAc}_{2} \mathrm{Hex}_{7} \mathrm{HexNAc}_{6}+\mathrm{Na}^{+}$ \\
\hline 2837 & $\mathrm{Hex}_{5} \mathrm{HexNAc}_{5} \mathrm{dHex}_{3}+\mathrm{Na}^{+}$ & 3719 & $\mathrm{NeuAc}_{1} \mathrm{Hex}_{6} \mathrm{HexNAc}_{7} \mathrm{dHex}_{2}+\mathrm{Na}^{+}$ \\
\hline 2850 & $\mathrm{NeuAc}_{1} \mathrm{Hex}_{5} \mathrm{HexNAc}_{5} \mathrm{dHex}_{1}+\mathrm{Na}^{+}$ & 3749 & $\mathrm{NeuAc}_{1} \mathrm{Hex}_{7} \mathrm{HexNAc}_{7} \mathrm{dHex}_{1}+\mathrm{Na}^{+}$ \\
\hline 2867 & $\mathrm{Hex}_{6} \mathrm{HexNAc}_{5} \mathrm{dHex}_{2}+\mathrm{Na}^{+}$ & 3764 & $\mathrm{NeuAc}_{2} \mathrm{Hex}_{6} \mathrm{HexNAc}_{5} \mathrm{dHex}_{3}+\mathrm{Na}^{+}$ \\
\hline 3779 & $\mathrm{NeuAc}_{1} \mathrm{Hex}_{8} \mathrm{HexNAc}_{7}+\mathrm{Na}^{+}$ & 4185 & $\mathrm{Hex}_{8} \mathrm{HexNAc}_{8} \mathrm{dHex}_{3}+\mathrm{Na}^{+}$ \\
\hline 3837 & $\mathrm{Hex}_{8} \mathrm{HexNAc}_{8} \mathrm{dHex}_{1}+\mathrm{Na}^{+}$ & 4215 & $\mathrm{Hex}_{9} \mathrm{HexNAc}_{8} \mathrm{dHex}_{2}+\mathrm{Na}^{+}$ \\
\hline 3865 & $\mathrm{NeuAc}_{2} \mathrm{Hex}_{7} \mathrm{HexNAc}_{6} \mathrm{dHex}_{1}+\mathrm{Na}^{+}$ & 4226 & $\mathrm{NeuAc}_{3} \mathrm{Hex}_{7} \mathrm{HexNAc}_{6} \mathrm{dHex}_{1}+\mathrm{Na}^{+}$ \\
\hline 3923 & $\mathrm{NeuAc}_{1} \mathrm{Hex}_{7} \mathrm{HexNAc}_{7} \mathrm{dHex}_{2}+\mathrm{Na}^{+}$ & 4284 & $\mathrm{NeuAc}_{2} \mathrm{Hex}_{7} \mathrm{HexNAc}_{7} \mathrm{dHex}_{2}+\mathrm{Na}^{+}$ \\
\hline 3936 & $\mathrm{NeuAc}_{2} \mathrm{Hex}_{7} \mathrm{HexNAc}_{7}+\mathrm{Na}^{+}$ & 4286 & $\mathrm{Hex}_{9} \mathrm{HexNAc}_{9} \mathrm{dHex}_{1}+\mathrm{Na}^{+}$ \\
\hline 3953 & $\mathrm{NeuAc}_{1} \mathrm{Hex}_{8} \mathrm{HexNAc}_{7} \mathrm{dHex}_{1}+\mathrm{Na}^{+}$ & 4297 & $\mathrm{NeuAc}_{3} \mathrm{Hex}_{7} \mathrm{HexNAc}_{7}+\mathrm{Na}^{+}$ \\
\hline 4011 & $\mathrm{Hex}_{8} \mathrm{HexNAc}_{8} \mathrm{dHex}_{2}+\mathrm{Na}^{+}$ & 4314 & $\mathrm{NeuAc}_{2} \mathrm{Hex}_{8} \mathrm{HexNAc}_{7} \mathrm{dHex}_{1}+\mathrm{Na}^{+}$ \\
\hline 4041 & $\mathrm{Hex}_{9} \mathrm{HexNAc}_{8} \mathrm{dHex}_{1}+\mathrm{Na}^{+}$ & 4402 & $\mathrm{NeuAc}_{1} \mathrm{Hex}_{9} \mathrm{HexNAc}_{8} \mathrm{dHex}_{1}+\mathrm{Na}^{+}$ \\
\hline 4052 & $\mathrm{NeuAc}_{3} \mathrm{Hex}_{7} \mathrm{HexNAc}_{6}+\mathrm{Na}^{+}$ & 4460 & $\mathrm{Hex}_{9} \mathrm{HexNAc}_{9} \mathrm{dHex}_{2}+\mathrm{Na}^{+}$ \\
\hline 4110 & $\mathrm{NeuAc}_{2} \mathrm{Hex}_{7} \mathrm{HexNAc}_{7} \mathrm{dHex}_{1}+\mathrm{Na}^{+}$ & 4471 & $\mathrm{NeuAc}_{3} \mathrm{Hex}_{7} \mathrm{HexNAc}_{7} \mathrm{dHex}_{1}+\mathrm{Na}^{+}$ \\
\hline
\end{tabular}

abundant hybrid type glycans; (iii) fucose and galactose are the other predominant residues at branched termini; (iv) after desialylation, 3-linked Gal and 6-linked Gal were diminished, indicating that sialic acid residues were attached at the 3- and 6-position of Gal prior to desialylation; ( $v$ ) the presence of 2-linked Man is indicative of bi-antennary structures; (vi) levels of 2,4-linked Man and 2,6-linked Man suggest that tri- and/or tetra-antennary structures are also present; (vii) the presence of terminal GlcNAc and 3,4,6-linked Man confirms the presence of bisected glycans; (viii) 4,6-linked GlcNAc and terminal fucose support the presence of core $\alpha 6$-fucosylation; and (ix) the presence of 3,4-linked GlcNAc suggests that some complex type glycans have antennae with a fucose residue.

Sequential exo-glycosidase digestions and hydrofluoric acid (HF) treatment To define the anomeric configurations as well as to confirm tentative sequences assignments, $\mathrm{N}$-glycans released by PNGase $\mathrm{F}$ were subjected to digestion with $\alpha$-sialidase, HF treatment, and $\beta$-galactosidase. Aliquots were taken after each treatment, the compounds permethylated, and examined by MALDI-TOF-MS.

After neuraminidase treatment, the MALDI-TOF-MS data indicated that all sialylated components previously 
Table 2 GC-MS analysis of partially methylated alditol acetates obtained from the PNGase F-released $N$-glycans.

\begin{tabular}{lllc}
\hline $\begin{array}{l}\text { Retention time } \\
(\mathrm{min})\end{array}$ & Characteristic fragment ions & Assignment & $\begin{array}{c}\text { Relative } \\
\text { abundance }\end{array}$ \\
\hline $15.51^{\mathrm{a}}$ & $115,118,131,162,175$ & Terminal fucose & 0.19 \\
20.38 & $102,118,129,145,161,162,205$ & Terminal mannose & 0.51 \\
$21.29^{\mathrm{b}}$ & $102,118,129,145,161,162,205$ & Terminal galactose & 0.35 \\
24.39 & $129,130,161,190$ & 2-Linked mannose & 0.48 \\
$25.31^{\mathrm{c}}$ & $118,129,161,234$ & 3-Linked galactose & 0.01 \\
$27.27^{\mathrm{d}}$ & $99,102,118,129,162,189,233$ & 6-Linked galactose & 0.03 \\
28.48 & $130,190,233$ & 2,4-Linked mannose & 0.14 \\
30.26 & $129,130,189,190$ & 2,6-Linked mannose & 0.19 \\
30.57 & $118,129,189,234$ & 3,6-Linked mannose & 0.18 \\
32.31 & 118,333 & 3,4,6-Linked mannose & 0.05 \\
33.50 & $117,159,203,205$ & Terminal GlcNAc & 0.14 \\
37.12 & $117,159,233$ & 4-Linked GlcNAc & 1.00 \\
$40.12^{\mathrm{e}}$ & $117,159,346$ & 3,4-Linked GlcNAc & 0.03 \\
41.42 & $117,159,261$ & 4,6-Linked GlcNAc & 0.19 \\
\hline
\end{tabular}

The $80 \%$ acetonitrile fractions from Sep-Pak purifications of permethylated glycans were hydrolyzed, reduced, acetylated and analyzed by gas chromatography-MS.

aSignals less intense after treatment of $N$-glycans with $\alpha$-neuraminidase and HF.

bSignals more intense after treatment of $N$-glycans with $\alpha$-neuraminidase.

cSignals less intense after treatment of $N$-glycans with $\alpha$-neuraminidase.

aSignals not observed after treatment of $N$-glycans with $\alpha$-neuraminidase.

eSignals not observed after treatment of $N$-glycans with $\alpha$-neuraminidase and $\mathrm{HF}$.

described (Figure 3 and Table 1) were converted into other compounds of reduced molecular weight consistent with the loss of one, two, or three sialic acid residues. The $[\mathrm{M}+\mathrm{Na}]^{+}$ions provide evidence for this change (Figure 4 and Table 3). For example, the molecular ions at $m / z 3749\left(\mathrm{NeuAc}_{1} \mathrm{Hex}_{7} \mathrm{HexNAc}_{7} \mathrm{dHex}_{1}\right), 4110\left(\mathrm{NeuAc}_{2}\right.$ $\mathrm{Hex}_{7} \mathrm{HexNAc}_{7} \mathrm{dHex}_{1}$ ), and 4471 (NeuAc $\mathrm{Hex}_{7} \mathrm{HexNAc}_{7}$ $\mathrm{dHex}_{1}$ ) disappeared concomitant with a significant increase in the abundance of the molecular ion at $\mathrm{m} / \mathrm{z}$ $3388\left(\mathrm{Hex}_{7} \mathrm{HexNAc}_{7} \mathrm{dHex}_{1}\right)$. Thus, the NeuAc residues are conjugated in regular $\alpha$-linkages. Data from MALDI-TOFMS of permethylated PNGase F-released glycans after sialidase digestion are summarized in Table 2. Compari- son of linkage data before and after sialidase treatment indicated that removal of terminal $\alpha-\mathrm{NeuAc}$ residues is accompanied by the decrease of 3-linked Gal and the loss of the 6-linked Gal (Table 2). These data suggest that $\alpha$-NeuAc is attached both at the 3- and 6-position of Gal. The neuraminidase treatment also revealed the presence of structures with the following compositions $\mathrm{Hex}_{10} \mathrm{HexNAc}_{9} \mathrm{dHex}_{1-3}$ ( $\mathrm{m} / \mathrm{z}$ 4490, 4664, and 4838). These structures probably correspond to minor sialylated $\mathrm{N}$-glycans not detected before the treatment.

To confirm that some complex type glycans have antennae with a fucose residue and produce fully defucosylated antennae for subsequent $\beta$-galactosidase

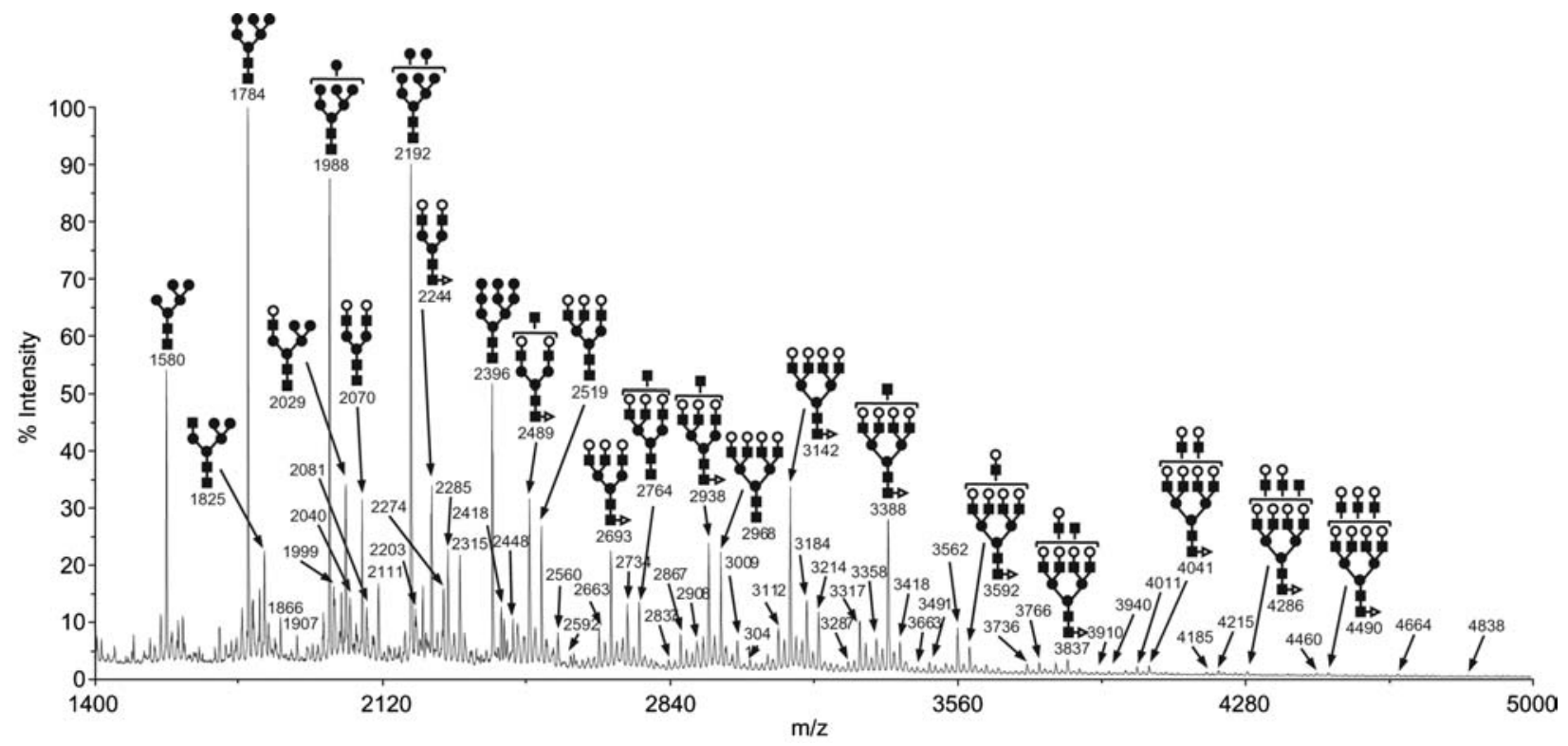

Figure 4 MALDI-TOF-MS spectrum of the permethylated PNGase F-released $\mathrm{N}$-glycans from brush border-enriched membrane fractions after neuraminidase digestion.

An aliquot was taken after digestion, permethylated, and purified by Sep-Pak. Only the structures of the major $N$-glycans are given. Symbols are as in Figure 3. The compositional assignment of the major signals is listed in Table 3. 
Table 3 Assignments of molecular $[\mathrm{M}+\mathrm{Na}]^{+}$ions observed in the MALDI spectrum of permethylated $\mathrm{N}$-glycans after neuraminidase digestion.

\begin{tabular}{|c|c|c|c|}
\hline $\begin{array}{l}\text { Signal } \\
(\mathrm{m} / \mathrm{z})\end{array}$ & Assignment & $\begin{array}{l}\text { Signal } \\
(\mathrm{m} / \mathrm{z})\end{array}$ & Assignment \\
\hline 1580 & $\mathrm{Hex}_{5} \mathrm{HexNAc}_{2}+\mathrm{Na}^{+}$ & 2938 & $\mathrm{Hex}_{6} \mathrm{HexNAc}_{6} \mathrm{dHex}_{1}+\mathrm{Na}^{+}$ \\
\hline 1784 & $\mathrm{Hex}_{6} \mathrm{HexNAc}_{2}+\mathrm{Na}^{+}$ & 2968 & $\mathrm{Hex}_{7} \mathrm{HexNAc}_{6}+\mathrm{Na}^{+}$ \\
\hline 1825 & $\mathrm{Hex}_{5} \mathrm{HexNAc}_{3}+\mathrm{Na}^{+}$ & 3009 & $\mathrm{Hex}_{6} \mathrm{HexNAc}_{7}+\mathrm{Na}^{+}$ \\
\hline 1866 & $\mathrm{Hex}_{4} \mathrm{HexNAc}_{4}+\mathrm{Na}^{+}$ & 3041 & $\mathrm{Hex}_{6} \mathrm{HexNAc}_{5} \mathrm{dHex}_{3}+\mathrm{Na}^{+}$ \\
\hline 1907 & $\mathrm{Hex}_{3} \mathrm{HexNAc}_{5}+\mathrm{Na}^{+}$ & 3112 & $\mathrm{Hex}_{6} \mathrm{HexNAc}_{6} \mathrm{dHex}_{2}+\mathrm{Na}^{+}$ \\
\hline 1988 & $\mathrm{Hex}_{7} \mathrm{HexNAc}_{2}+\mathrm{Na}^{+}$ & 3142 & $\mathrm{Hex}_{7} \mathrm{HexNAc}_{6} \mathrm{dHex}_{1}+\mathrm{Na}^{+}$ \\
\hline 1999 & $\mathrm{Hex}_{5} \mathrm{HexNAc}_{3} \mathrm{dHex}_{1}+\mathrm{Na}^{+}$ & 3184 & $\mathrm{Hex}_{6} \mathrm{HexNAc}_{7} \mathrm{dHex}_{1}+\mathrm{Na}^{+}$ \\
\hline 2029 & $\mathrm{Hex}_{6} \mathrm{HexNAc}_{3}+\mathrm{Na}^{+}$ & 3214 & $\mathrm{Hex}_{7} \mathrm{HexNAc}_{7}+\mathrm{Na}^{+}$ \\
\hline 2040 & $\mathrm{Hex}_{4} \mathrm{HexNAc}_{4} \mathrm{dHex}_{1}+\mathrm{Na}^{+}$ & 3287 & $\mathrm{Hex}_{6} \mathrm{HexNAc}_{6} \mathrm{dHex}_{3}+\mathrm{Na}^{+}$ \\
\hline 2070 & $\mathrm{Hex}_{5} \mathrm{HexNAc}_{4}+\mathrm{Na}^{+}$ & 3317 & $\mathrm{Hex}_{7} \mathrm{HexNAc}_{6} \mathrm{dHex}_{2}+\mathrm{Na}^{+}$ \\
\hline 2081 & $\mathrm{Hex}_{3} \mathrm{HexNAc}_{5} \mathrm{dHex}_{1}+\mathrm{Na}^{+}$ & 3358 & $\mathrm{Hex}_{6} \mathrm{HexNAc}_{7} \mathrm{dHex}_{2}+\mathrm{Na}^{+}$ \\
\hline 2111 & $\mathrm{Hex}_{4} \mathrm{HexNAc}_{5}+\mathrm{Na}^{+}$ & 3388 & $\mathrm{Hex}_{7} \mathrm{HexNAc}_{7} \mathrm{dHex}_{1}+\mathrm{Na}^{+}$ \\
\hline 2192 & $\mathrm{Hex}_{8} \mathrm{HexNAc}_{2}+\mathrm{Na}^{+}$ & 3418 & $\mathrm{Hex}_{8} \mathrm{HexNAc}_{7}+\mathrm{Na}^{+}$ \\
\hline 2203 & $\mathrm{Hex}_{6} \mathrm{HexNAc}_{3} \mathrm{dHex}_{1}+\mathrm{Na}^{+}$ & 3491 & $\mathrm{Hex}_{7} \mathrm{HexNAc}_{6} \mathrm{dHex}_{3}+\mathrm{Na}^{+}$ \\
\hline 2244 & $\mathrm{Hex}_{5} \mathrm{HexNAc}_{4} \mathrm{dHex}_{1}+\mathrm{Na}^{+}$ & 3562 & $\mathrm{Hex}_{7} \mathrm{HexNAc}_{7} \mathrm{dHex}_{2}+\mathrm{Na}^{+}$ \\
\hline 2274 & $\mathrm{Hex}_{6} \mathrm{HexNAc}_{4}+\mathrm{Na}^{+}$ & 3592 & $\mathrm{Hex}_{8} \mathrm{HexNAc}_{7} \mathrm{dHex}_{1}+\mathrm{Na}^{+}$ \\
\hline 2285 & $\mathrm{Hex}_{4} \mathrm{HexNAc}_{5} \mathrm{dHex}_{1}+\mathrm{Na}^{+}$ & 3663 & $\mathrm{Hex}_{8} \mathrm{HexNAc}_{8}+\mathrm{Na}^{+}$ \\
\hline 2315 & $\mathrm{Hex}_{5} \mathrm{HexNAc}_{5}+\mathrm{Na}^{+}$ & 3736 & $\mathrm{Hex}_{7} \mathrm{HexNAc}_{7} \mathrm{dHex}_{3}+\mathrm{Na}^{+}$ \\
\hline 2396 & $\mathrm{Hex}_{9} \mathrm{HexNAc}_{2}+\mathrm{Na}^{+}$ & 3766 & $\mathrm{Hex}_{8} \mathrm{HexNAc}_{7} \mathrm{dHex}_{2}+\mathrm{Na}^{+}$ \\
\hline 2418 & $\mathrm{Hex}_{5} \mathrm{HexNAc}_{4} \mathrm{dHex}_{2}+\mathrm{Na}^{+}$ & 3837 & $\mathrm{Hex}_{8} \mathrm{HexNAc}_{8} \mathrm{dHex}_{1}+\mathrm{Na}^{+}$ \\
\hline 2448 & $\mathrm{Hex}_{6} \mathrm{HexNAc}_{4} \mathrm{dHex}_{1}+\mathrm{Na}^{+}$ & 3910 & $\mathrm{Hex}_{7} \mathrm{HexNAc}_{7} \mathrm{dHex}_{4}+\mathrm{Na}^{+}$ \\
\hline 2489 & $\mathrm{Hex}_{5} \mathrm{HexNAc}_{5} \mathrm{dHex}_{1}+\mathrm{Na}^{+}$ & 3940 & $\mathrm{Hex}_{8} \mathrm{HexNAc}_{7} \mathrm{dHex}_{3}+\mathrm{Na}^{+}$ \\
\hline 2519 & $\mathrm{Hex}_{6} \mathrm{HexNAc}_{5}+\mathrm{Na}^{+}$ & 4011 & $\mathrm{Hex}_{8} \mathrm{HexNAc}_{8} \mathrm{dHex}_{2}+\mathrm{Na}^{+}$ \\
\hline 2560 & $\mathrm{Hex}_{5} \mathrm{HexNAc}_{6}+\mathrm{Na}^{+}$ & 4041 & $\mathrm{Hex}_{9} \mathrm{HexNAc}_{8} \mathrm{dHex}_{1}+\mathrm{Na}^{+}$ \\
\hline 2592 & $\mathrm{Hex}_{5} \mathrm{HexNAc}_{4} \mathrm{dHex}_{3}+\mathrm{Na}^{+}$ & 4185 & $\mathrm{Hex}_{8} \mathrm{HexNAc}_{8} \mathrm{dHex}_{3}+\mathrm{Na}^{+}$ \\
\hline 2663 & $\mathrm{Hex}_{5} \mathrm{HexNAc}_{5} \mathrm{dHex}_{2}+\mathrm{Na}^{+}$ & 4215 & $\mathrm{Hex}_{9} \mathrm{HexNAc}_{8} \mathrm{dHex}_{2}+\mathrm{Na}^{+}$ \\
\hline 2693 & $\mathrm{Hex}_{6} \mathrm{HexNAc}_{5} \mathrm{dHex}_{1}+\mathrm{Na}^{+}$ & 4286 & $\mathrm{Hex}_{9} \mathrm{HexNAc}_{9} \mathrm{dHex}_{1}+\mathrm{Na}^{+}$ \\
\hline 2734 & $\mathrm{Hex}_{5} \mathrm{HexNAc}_{6} \mathrm{dHex}_{1}+\mathrm{Na}^{+}$ & 4460 & $\mathrm{Hex}_{9} \mathrm{HexNAc}_{9} \mathrm{dHex}_{2}+\mathrm{Na}^{+}$ \\
\hline 2764 & $\mathrm{Hex}_{6} \mathrm{HexNAc}_{6}+\mathrm{Na}^{+}$ & 4490 & $\mathrm{Hex}_{10} \mathrm{HexNAc}_{9} \mathrm{dHex}_{1}+\mathrm{Na}^{+}$ \\
\hline 2837 & $\mathrm{Hex}_{5} \mathrm{HexNAc}_{5} \mathrm{dHex}_{3}+\mathrm{Na}^{+}$ & 4664 & $\mathrm{Hex}_{10} \mathrm{HexNAc}_{9} \mathrm{dHex}_{2}+\mathrm{Na}^{+}$ \\
\hline 2867 & $\mathrm{Hex}_{6} \mathrm{HexNAc}_{5} \mathrm{dHex}_{2}+\mathrm{Na}^{+}$ & 4838 & $\mathrm{Hex}_{10} \mathrm{HexNAc}_{9} \mathrm{dHex}_{3}+\mathrm{Na}^{+}$ \\
\hline 2908 & $\mathrm{Hex}_{5} \mathrm{HexNAc}_{6} \mathrm{dHex}_{2}+\mathrm{Na}^{+}$ & & \\
\hline
\end{tabular}

digestion, we subjected the desialylated $\mathrm{N}$-glycans to HF treatment. Incubation of fucosylated glycans with $\mathrm{HF}$ results in the rapid hydrolysis of Fuc $\alpha 1-3 \mathrm{GlcNAc}$ linkages and slower release of $\alpha 1$-2-linked fucose, whereas the $\alpha 1-6$-linked fucose residues linked to the $N$-glycan cores are relatively resistant (Haslam et al., 2000). After treatment, an aliquot was taken for permethylation, purification by Sep-Pak, and analysis by MALDI-TOF-MS (Figure 5). Data from MALDI-TOF-MS of permethylated PNGase F-released glycans after sialidase digestion and $\mathrm{HF}$ treatment are summarized in Table 4. Incubation with $\mathrm{HF}$ yielded a less complex spectrum and no evidence for signals corresponding to glycans which have more than one fucose residue. These data strongly suggest that most of the fucosylated $\mathrm{N}$-glycans carry a fucose residue on the core.

Figure 6 shows part of the MALDI-TOF-MS profile for the permethylated $N$-glycans after $\beta$-galactosidase treatment. The glycans that were previously observed at $\mathrm{m} / \mathrm{z}$ 2029, 2040, 2070, 2111, 2244, 2274, 2285, 2315, 2489, 2519, 2560, 2693, 2734, 2764, 2938, 2968, 3009, 3142, 3184,3214 , and 3388 in the undigested sample were absent. These data indicated that the components were efficiently degalactosylated by $\beta$-galactosidase from bovine testes. This treatment confirmed the presence of tri- and tetra-antennary structures. For example, the ion at $\mathrm{m} / \mathrm{z} 2968\left(\mathrm{Hex}_{7} \mathrm{HexNAc}_{6}\right.$ ) has shifted to $\mathrm{m} / \mathrm{z} 2152$ $\left(\mathrm{Hex}_{3} \mathrm{HexNAc}_{6}\right)$, which reflects the loss of four galactose units and accordingly is very likely to stem from a tetra- antennary structure. The glycans at $\mathrm{m} / \mathrm{z} 2693\left(\mathrm{Hex}_{6}\right.$ $\left.\mathrm{HexNAc}_{5} \mathrm{dHex}_{1}\right)$ and $2938\left(\mathrm{Hex}_{6} \mathrm{HexNAc}_{6} \mathrm{dHex}_{1}\right)$ have also shifted to $\mathrm{m} / \mathrm{z} 2081\left(\mathrm{Hex}_{3} \mathrm{HexNAc}_{5} \mathrm{dHex}_{1}\right)$ and 2326 $\left(\mathrm{Hex}_{3} \mathrm{HexNAc}_{6} \mathrm{dHex}_{1}\right)$, respectively, consistent with the loss of galactose residues from tri-antennary structures. The presence of structures with poly- $N$-acetyllactosamine extensions that were partially resistant to the $\beta$ galactosidase digestions was also confirmed. The glycans that were previously observed at $\mathrm{m} / \mathrm{z} 3418$, $3592,3663,3837,4041,4286$, and 4490 have shifted to $\mathrm{m} / \mathrm{z} 2601,2775,2846,3020,3225,3470$, and 3674.

Characterization of $\mathbf{N}$-glycan structures by ESIQTOF-MS/MS After desialylation, the permethylated $\mathrm{N}$-glycans were analyzed using nano-ESI-QTOF-MS/MS. The fragments originating from both the reducing and the non-reducing ends of the glycan yield information on sequence and branching (Morelle et al., 2004). Representative data derived from the fragmentation of the $[\mathrm{M}+2 \mathrm{Na}]^{2+}$ of the molecular ions of the complex $\mathrm{N}$-glycans $\mathrm{Fuc}_{1} \mathrm{Hex}_{5} \mathrm{HexNAc}_{4}, \quad \mathrm{Fuc}_{2} \mathrm{Hex}_{5} \mathrm{HexNAc}_{4}$, and $\mathrm{Fuc}_{1} \mathrm{Hex}_{5} \mathrm{HexNAc}_{5}$ are shown in Figure 7A-C. Assignments of key signals are given. As shown in Figure 6A, MS/MS analysis of the $[\mathrm{M}+2 \mathrm{Na}]^{2+}$ at $\mathrm{m} / \mathrm{z} 1134$ yielded a spectrum dominated by a fragment ion at $m / z 486\left(\mathrm{Hex}_{1}\right.$ Hex $\left.N A c_{1}\right)$. The presence of this fragment and the low abundance of the fragment at $\mathrm{m} / \mathrm{z} 660\left(\mathrm{Fuc}_{1}-\mathrm{Hex}_{1}-\right.$ HexNAc${ }_{1}$ ) suggests that the majority of the fucose moieties is on the core rather than one of the antennae. The 


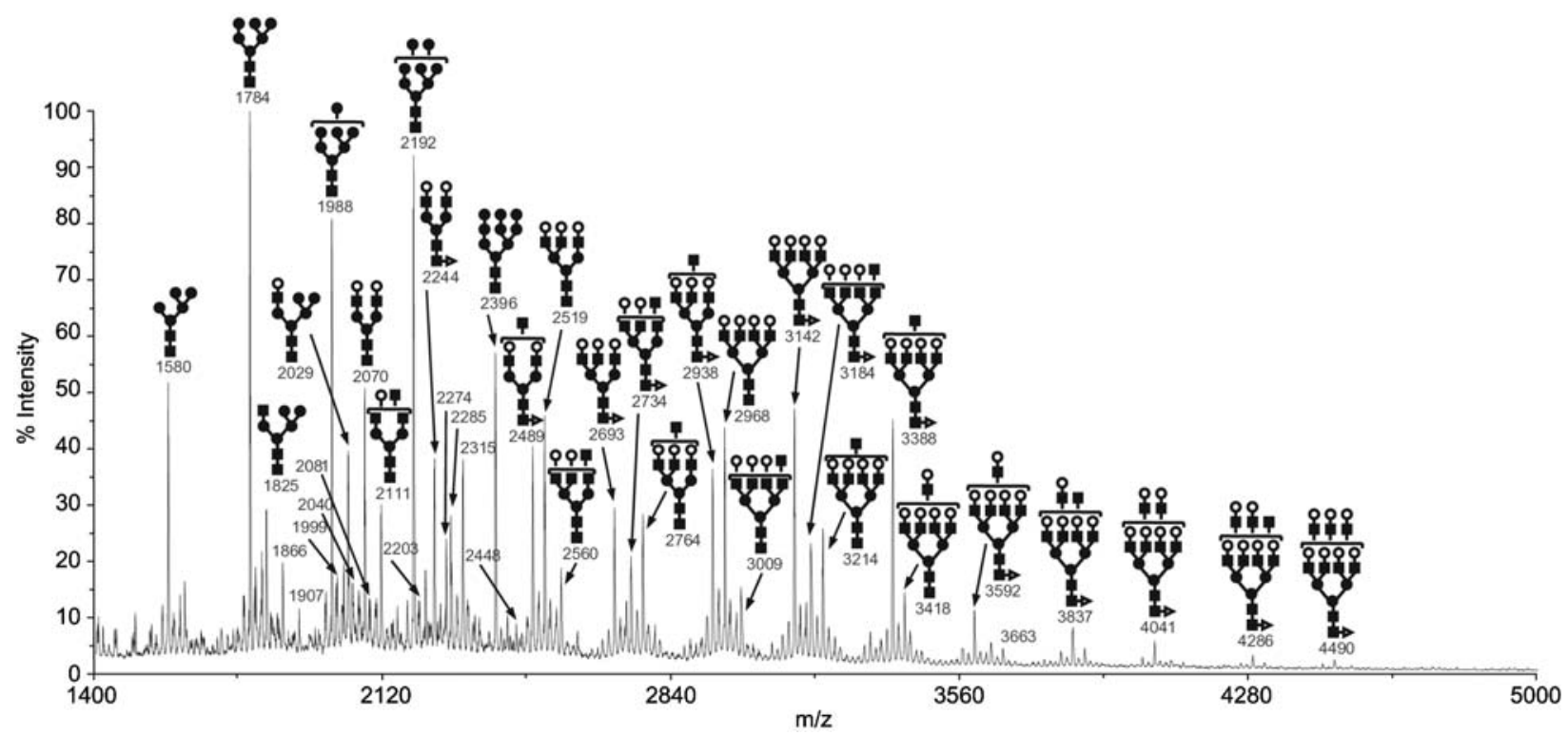

Figure 5 MALDI-TOF-MS spectrum of the permethylated PNGase F-released N-glycans from brush border-enriched membranes after neuraminidase digestion and $\mathrm{HF}$ treatment.

An aliquot was taken after HF treatment, permethylated, and purified by Sep-Pak. Only the structures of the major $N$-glycans are given. Symbols are as in Figure 3. The compositional assignment of the major signals is listed in Table 4.

MS/MS spectrum of the $\mathrm{N}$-glycan $\mathrm{Fuc}_{2} \mathrm{Hex}_{5} \mathrm{HexNAc}_{4}$ is characterized by the presence of diagnostic ions at $\mathrm{m} / \mathrm{z}$ 474, 486, and 660 (Figure 6B). The ion at $\mathrm{m} / \mathrm{z} 474$ corresponds to the diagnostic signal for fucose being attached to the terminal GlcNAc of the core. As the major fragment ions are at $m / z 486$ and 660 , the majority of the glycans of the composition $\mathrm{Fuc}_{2} \mathrm{Hex}_{5} \mathrm{HexNAc}_{4}$ carry one fucose on the core and one on the antennae. In contrast, the monofucosylated glycans with the composition Fuc $_{1} \mathrm{Hex}_{5} \mathrm{HexNAc}_{5}$ show a major signal at $\mathrm{m} / \mathrm{z} 486$ and a minor signal at $\mathrm{m} / \mathrm{z} 660$, indicating that these glycans are predominantly fucosylated on the core (Figure $7 \mathrm{C}$ ).
Structural conclusions on PNGase F-released glycans Taking into consideration the MALDI-TOF-MS, linkage, sequential exoglycosidase, HF treatment, MS/ MS data, and knowledge of the biosynthetic pathways of $\mathrm{N}$-glycans, we conclude that the major $\mathrm{N}$-glycans have the structures shown in Figure 8.

O-Glycosylation analysis Reductive elimination on de- $N$-glycosylated peptides was carried out in order to determine the major O-glycan structures. After Dowex purification, borate removal, the $\mathrm{O}$-glycans were permethylated, purified on a C18 Sep-Pak cartridge, and ana-

Table 4 Assignments of molecular $[\mathrm{M}+\mathrm{Na}]^{+}$ions observed in the MALDI spectrum of permethylated $\mathrm{N}$-glycans after neuraminidase digestion and $\mathrm{HF}$ treatment.

\begin{tabular}{|c|c|c|c|}
\hline $\begin{array}{l}\text { Signal } \\
(\mathrm{m} / \mathrm{z})\end{array}$ & Assignment & $\begin{array}{c}\text { Signal } \\
(\mathrm{m} / \mathrm{z})\end{array}$ & Assignment \\
\hline 1580 & $\mathrm{Hex}_{5} \mathrm{HexNAc}_{2}+\mathrm{Na}^{+}$ & 2489 & $\mathrm{Hex}_{5} \mathrm{HexNAc}_{5} \mathrm{dHex}_{1}+\mathrm{Na}^{+}$ \\
\hline 1784 & $\mathrm{Hex}_{6} \mathrm{HexNAc}_{2}+\mathrm{Na}^{+}$ & 2519 & $\mathrm{Hex}_{6} \mathrm{HexNAc}_{5}+\mathrm{Na}^{+}$ \\
\hline 1825 & $\mathrm{Hex}_{5} \mathrm{HexNAc}_{3}+\mathrm{Na}^{+}$ & 2560 & $\mathrm{Hex}_{5} \mathrm{HexNAc}_{6}+\mathrm{Na}^{+}$ \\
\hline 1866 & $\mathrm{Hex}_{4} \mathrm{HexNAc}_{4}+\mathrm{Na}^{+}$ & 2693 & $\mathrm{Hex}_{6} \mathrm{HexNAc}_{5} \mathrm{dHex}_{1}+\mathrm{Na}^{+}$ \\
\hline 1907 & $\mathrm{Hex}_{3} \mathrm{HexNAc}_{5}+\mathrm{Na}^{+}$ & 2734 & $\mathrm{Hex}_{5} \mathrm{HexNAc}_{6} \mathrm{dHex}_{1}+\mathrm{Na}^{+}$ \\
\hline 1988 & $\mathrm{Hex}_{7} \mathrm{HexNAc}_{2}+\mathrm{Na}^{+}$ & 2764 & $\mathrm{Hex}_{6} \mathrm{HexNAc}_{6}+\mathrm{Na}^{+}$ \\
\hline 1999 & $\mathrm{Hex}_{5} \mathrm{HexNAc}_{3} \mathrm{dHex}_{1}+\mathrm{Na}^{+}$ & 2938 & $\mathrm{Hex}_{6} \mathrm{HexNAc}_{6} \mathrm{dHex}_{1}+\mathrm{Na}^{+}$ \\
\hline 2029 & $\mathrm{Hex}_{6} \mathrm{HexNAc}_{3}+\mathrm{Na}^{+}$ & 2968 & $\mathrm{Hex}_{7} \mathrm{HexNAc}_{6}+\mathrm{Na}^{+}$ \\
\hline 2040 & $\mathrm{Hex}_{4} \mathrm{HexNAc}_{4} \mathrm{dHex}_{1}+\mathrm{Na}^{+}$ & 3009 & $\mathrm{Hex}_{6} \mathrm{HexNAc}_{7}+\mathrm{Na}^{+}$ \\
\hline 2070 & $\mathrm{Hex}_{5} \mathrm{HexNAc}_{4}+\mathrm{Na}^{+}$ & 3142 & $\mathrm{Hex}_{7} \mathrm{HexNAc}_{6} \mathrm{dHex}_{1}+\mathrm{Na}^{+}$ \\
\hline 2081 & $\mathrm{Hex}_{3} \mathrm{HexNAc}_{5} \mathrm{dHex}_{1}+\mathrm{Na}^{+}$ & 3184 & $\mathrm{Hex}_{6} \mathrm{HexNAc}_{7} \mathrm{dHex}_{1}+\mathrm{Na}^{+}$ \\
\hline 2111 & $\mathrm{Hex}_{4} \mathrm{HexNAc}_{5}+\mathrm{Na}^{+}$ & 3214 & $\mathrm{Hex}_{7} \mathrm{HexNAc}_{7}+\mathrm{Na}^{+}$ \\
\hline 2192 & $\mathrm{Hex}_{8} \mathrm{HexNAc}_{2}+\mathrm{Na}^{+}$ & 3388 & $\mathrm{Hex}_{7} \mathrm{HexNAc}_{7} \mathrm{dHex}_{1}+\mathrm{Na}^{+}$ \\
\hline 2203 & $\mathrm{Hex}_{6} \mathrm{HexNAc}_{3} \mathrm{dHex}_{1}+\mathrm{Na}^{+}$ & 3418 & $\mathrm{Hex}_{8} \mathrm{HexNAc}_{7}+\mathrm{Na}^{+}$ \\
\hline 2244 & $\mathrm{Hex}_{5} \mathrm{HexNAc}_{4} \mathrm{dHex}_{1}+\mathrm{Na}^{+}$ & 3592 & $\mathrm{Hex}_{8} \mathrm{HexNAc}_{7} \mathrm{dHex}_{1}+\mathrm{Na}^{+}$ \\
\hline 2274 & $\mathrm{Hex}_{6} \mathrm{HexNAc}_{4}+\mathrm{Na}^{+}$ & 3663 & $\mathrm{Hex}_{8} \mathrm{HexNAc}_{8}+\mathrm{Na}^{+}$ \\
\hline 2285 & $\mathrm{Hex}_{4} \mathrm{HexNAc}_{5} \mathrm{dHex}_{1}+\mathrm{Na}^{+}$ & 3837 & $\mathrm{Hex}_{8} \mathrm{HexNAc}_{8} \mathrm{dHex}_{1}+\mathrm{Na}^{+}$ \\
\hline 2315 & $\mathrm{Hex}_{5} \mathrm{HexNAc}_{5}+\mathrm{Na}^{+}$ & 4041 & $\mathrm{Hex}_{9} \mathrm{HexNAc}_{8} \mathrm{dHex}_{1}+\mathrm{Na}^{+}$ \\
\hline 2396 & $\mathrm{Hex}_{9} \mathrm{HexNAc}_{2}+\mathrm{Na}^{+}$ & 4286 & $\mathrm{Hex}_{9} \mathrm{HexNAc}_{9} \mathrm{dHex}_{1}+\mathrm{Na}^{+}$ \\
\hline 2448 & $\mathrm{Hex}_{6} \mathrm{HexNAc}_{4} \mathrm{dHex}_{1}+\mathrm{Na}^{+}$ & 4490 & $\mathrm{Hex}_{10} \mathrm{HexNAc}_{9} \mathrm{dHex}_{1}+\mathrm{Na}^{+}$ \\
\hline
\end{tabular}




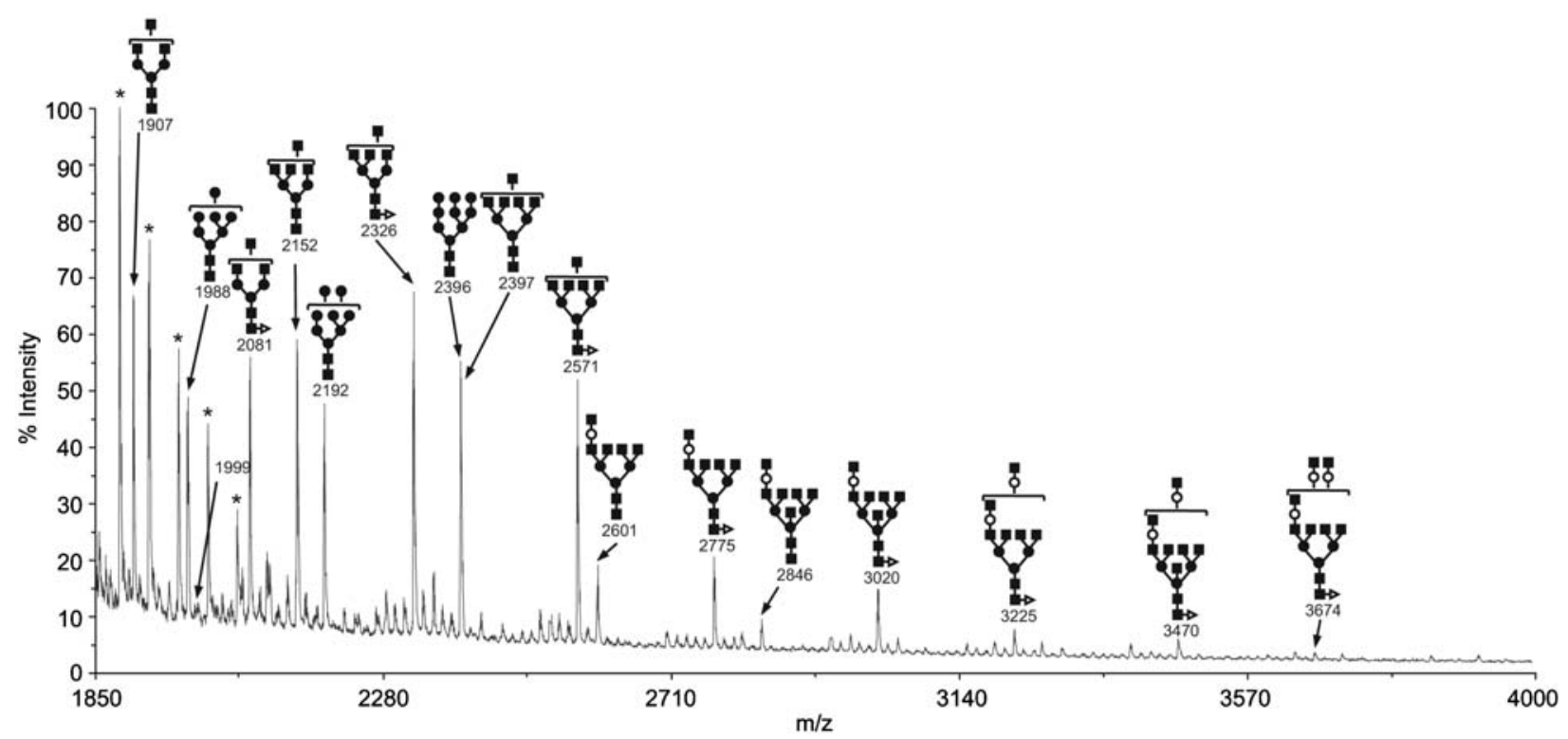

Figure 6 MALDI-TOF-MS spectrum of the permethylated PNGase F-released $N$-glycans from brush border-enriched membranes after neuraminidase digestion, HF treatment, and $\beta$-galactosidase digestion.

An aliquot was taken after $\beta$-galactosidase digestion, permethylated, and purified by Sep-Pak. Only the structures of the major $N$ glycans are given. Symbols are as in Figure 3.

lyzed by MALDI-TOF-MS (Figure 9). Two major molecular ions were observed at $\mathrm{m} / \mathrm{z} 895$ (Neu5Ac${ }_{1} \mathrm{Hex}_{1} \mathrm{HexNAcitol)}$

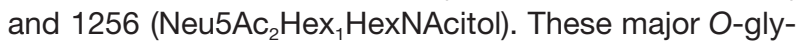
cans are consistent with sialylated and bisialylated T-antigen structures [Neu5Aco2-3Gal/31-3GalNAc-ol and Neu5Ac $\alpha 2-3 G a l \alpha 1-3($ Neu5Ac $\alpha 2-6)$ GalNAc-ol].

\section{Inhibition of the processing of $\mathbf{N}$-glycans abolishes the apical targeting of MUC1}

MUC1 is a membrane glycoprotein which is extensively O-glycosylated in its extracellular domain with tandem repeats, and also carries $\mathrm{N}$-glycan chains near the transmembrane domain. In order to address the issue as for the role of $N$-glycans in the apical delivery of MUC1, we analyzed its trafficking in the presence of 1-deoxymannojirimycin, an inhibitor of $\alpha 1-2$ mannosidase I which inhibits the trimming of $\mathrm{Man}_{9} \mathrm{GlcNAc}_{2}$ to $\mathrm{Man}_{8} \mathrm{GlcNAc}_{2}$, and consequently blocks the $\mathrm{N}$-glycan processing into hybrid type and complex type $N$-glycans. Thus, in presence of this inhibitor, the $N$-glycans are all high mannosetype glycans. HT-29 5M12 cells were treated with $1 \mathrm{mM}$ 1-deoxymannojirimycin for $24 \mathrm{~h}$ and then processed for confocal microscopy (Figure 10A). As previously reported, MUC1 is exclusively localized at the apical brush border of HT-29 5M12 cells. In HT-29 5M12 cells treated with 1-deoxymannojirimycin, MUC1 was no longer localized at the apical surface but was retained intracellularly. In addition, the apical cell culture medium of 1-deoxymannojirimycin HT-29 5M12-treated cells contained no extracellular MUC1 ectodomain normally shed from cell surfaces (Figure 10B). These results clearly showed that the maturation of the $\mathrm{N}$-glycans of MUC1 was essential for the apical delivery of this membrane mucin in HT-29 $5 \mathrm{M} 12$ cells.

\section{Discussion}

Our previous work has demonstrated that the tandem repeat-type galectin-4 regulates the raft-dependent delivery of glycoproteins to the apical brush border membrane of enterocyte-like HT-29 cells. Silencing of galectin-4 expression using RNAi inhibited the apical targeting of the brush border glycoproteins, as shown for dipeptidyl peptidase IV (DPP-IV), carcinoembryonic antigen (CEA), and mucin-like membrane MUC1, which remained abnormally accumulated inside the galectin-4depleted HT-29 5M12 cells. Galectin-4, synthesized on free cytoplasmic ribosomes, is externalized from the cytosol to the apical medium, then re-internalized from the apical surface, and finally follows an apical recycling pathway which drives the raft-dependent apical pathway of newly synthesized glycoproteins to the brush border membrane. This lectin has a high affinity for glycosphingolipids, which are typical lipid components of lipid rafts, and is a major constituent of DRMs. Galectin-4 is responsible for the recruitment of apical glycoproteins within DRMs, and the avidity of galectin-4 for these raft-associated glycoproteins is supported by their high density of complex type $N$-glycans with the $N$-acetyllactosamine sequence Galß1-4GlcNAc (Delacour et al., 2005; Stechly et al., 2009).

The purpose of this work was to analyze the potential contribution of $\mathrm{N}$ - and/or O-glycans in the galectin-4dependent apical delivery of membrane proteins. Structural studies using MALDI-TOF-MS and nano-ESI-QTOFMS-MS were carried out on the brush border membraneenriched fraction isolated from enterocytic HT-29 5M12 cells. Results showed that the pattern of $N$-glycans of the brush border membrane glycoproteins was very heterogeneous, with the presence of high mannose-type glycans, hybrid type glycans, and a multitude of complex 

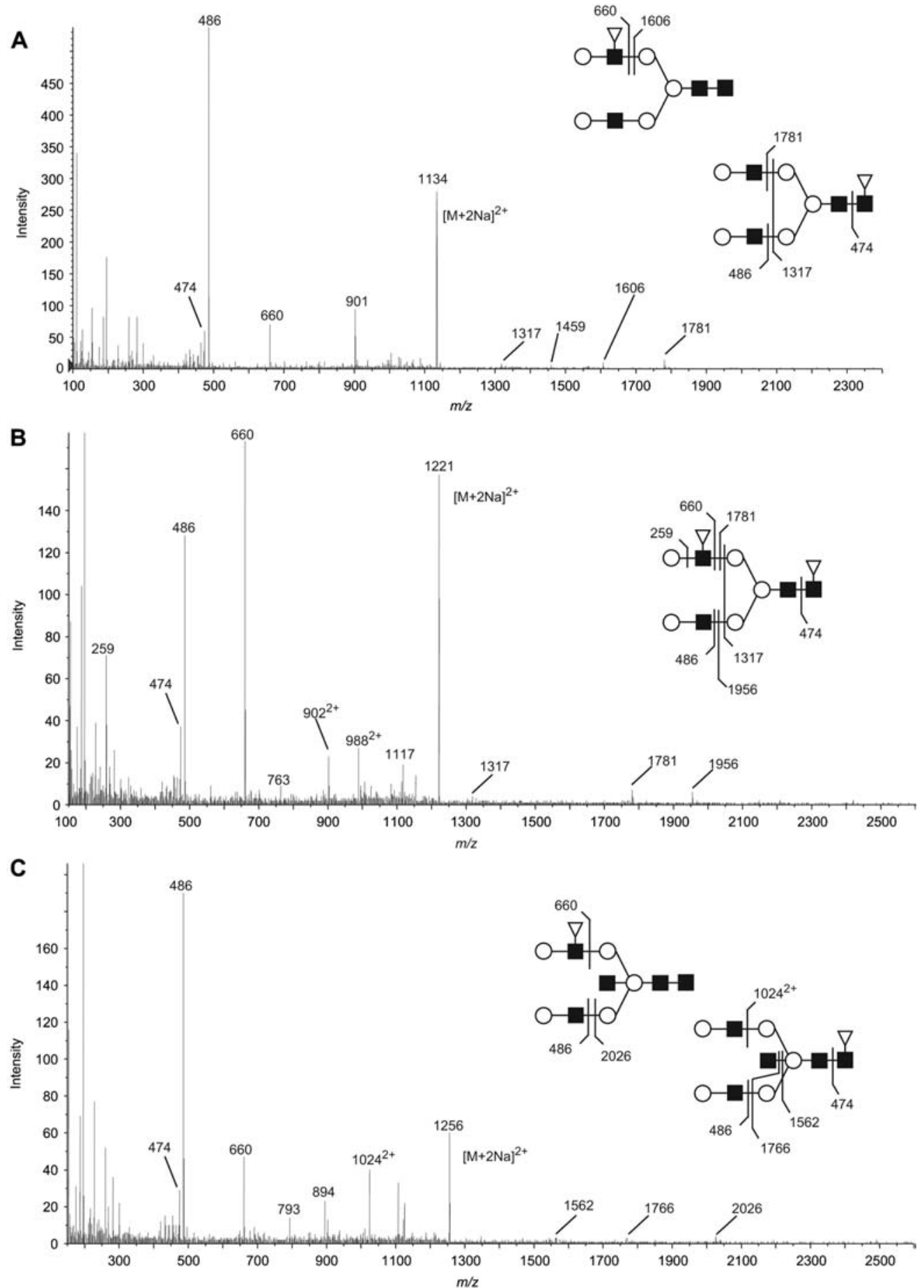

Figure 7 Nano-electrospray MS-MS spectra of the $[\mathrm{M}+2 \mathrm{Na}]^{2+}$ molecular ions of the permethylated $\mathrm{N}$-glycans $\mathrm{Fuc}_{1} \mathrm{Hex}_{5} \mathrm{HexNAc}_{4}$ (A), $\mathrm{Fuc}_{2} \mathrm{Hex}_{5} \mathrm{HexNAc}_{4}(\mathrm{~B})$, and $\mathrm{Fuc}_{1} \mathrm{Hex}_{5} \mathrm{HexNAc}_{5}(\mathrm{C})$.

Symbols are as in Figure 3.

type $\mathrm{N}$-glycans. This group consisted of bi-antennary, triantennary, and tetra-antennary glycans, substituted by fucose and/or sialic acid. Fucose was found on the core and on the antennae. Sialic acid was found in $\alpha 2-6$ or $\alpha 2-3$ linkage to a galactose residue. Interestingly, the $N$ glycosylation pattern of the brush border membrane included the complex type $\mathrm{N}$-glycans that were found enriched in DRMs isolated from HT-29 5M12 cells, i.e., bi-antennary $(\mathrm{m} / \mathrm{z} 2070,2244,2315,2418,2489)$, triantennary $(\mathrm{m} / \mathrm{z} 2519,2764,2867,2938,3112)$, and tetraantennary $(\mathrm{m} / \mathrm{z} 2968,3142,3214,3388,3562,3909)$ structures. In contrast to the diversity of $N$-glycans, the pattern of O-glycans of the brush border glycoproteins was very simple with the presence of two major core type 1 O-glycans, i.e., sialylated and bisialylated T-antigen structures [Neu5Ac $\alpha 2-3 \mathrm{Gal} \beta 1-3 \mathrm{GaINAc}-\mathrm{ol}$ and Neu5 Ac $\alpha 2-3 G$ Gal $\beta 1-3(N e u 5 A c \alpha 2-6)$ GalNAc-ol]. Studies of the carbohydrate-binding specificity of galectin-4 has identified sulfated core-type $1 \mathrm{SO}_{3}$-Gal $\beta 1$-3GalNAc pyranoside as well as sulfated glycosphingolipids as high affinity ligands for galectin-4, but in contrast, Neu5Ac23Gal $31-3 G a l N A c$ had very weak affinity for galectin-4 (Ideo et al., 2002, 2005; Delacour et al., 2005). Therefore, the major O-glycans of the brush border membrane- 

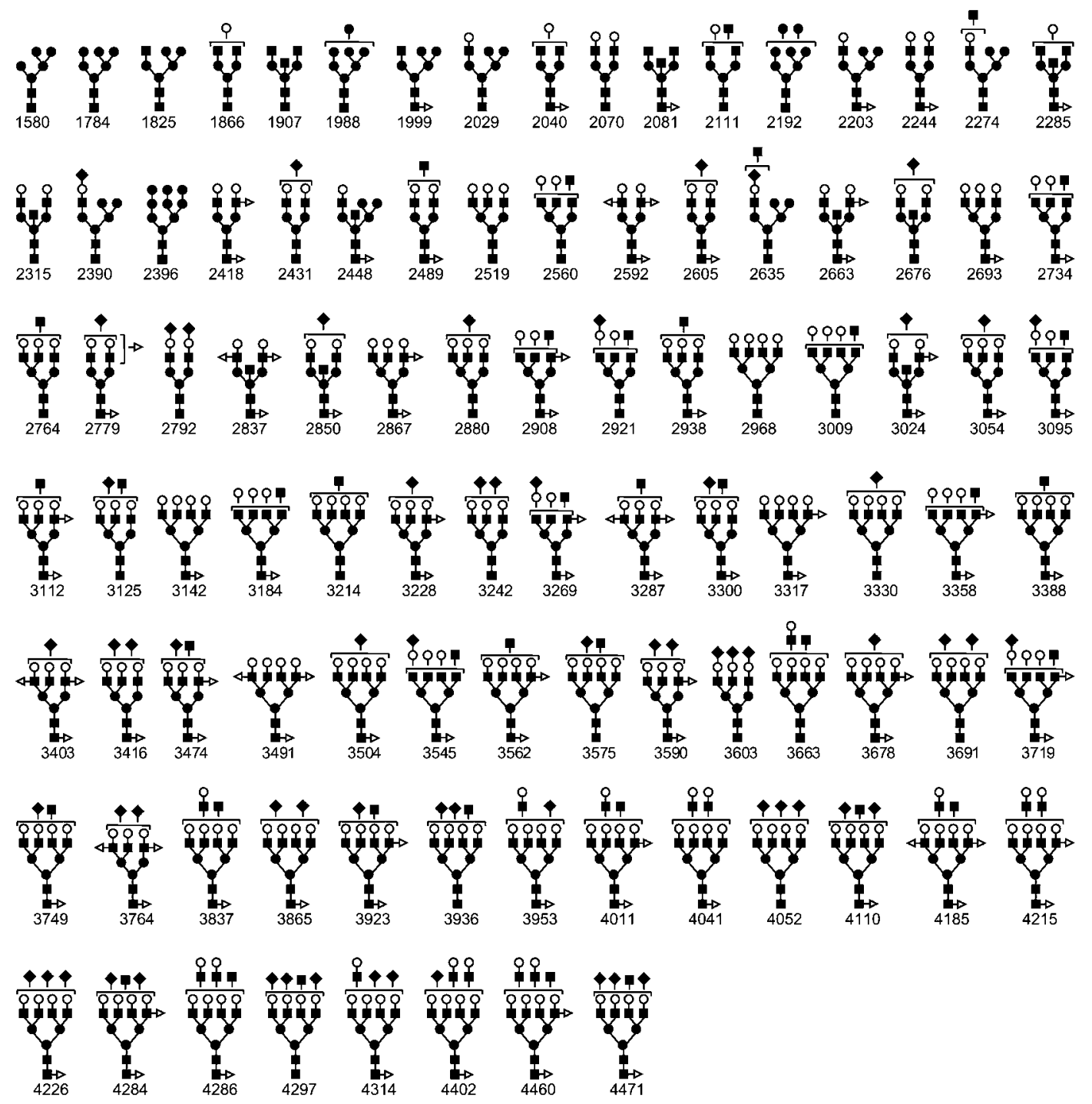

Figure 8 Structures proposed for the major $\mathrm{N}$-glycans released from brush border-enriched membranes.

Symbols are as in Figure 3. A minor portion of the fucosylated glycans carries fucose on an antenna rather than the core.

enriched fraction of HT-29 5M12 cells are apparently not ligands of galectin-4 and can consequently not be involved in the galectin-4-dependent trafficking.

The transmembrane glycoproteins DPP-IV and MUC1 and the glycosylphosphatidylinositol (GPI)-anchored glycoproteins CD-59 and CEA are expressed at the apical brush border of HT-29 5M12 cells and are associated with DRMs of these cells (Delacour et al., 2005; Stechly et al., 2009). These glycoproteins are known to have different degrees of $\mathrm{N}$ - and/or O-glycosylation. The structural study of CEA purified from liver metastases of colon cancer showed the presence of $25 \mathrm{~N}$-glycans, including

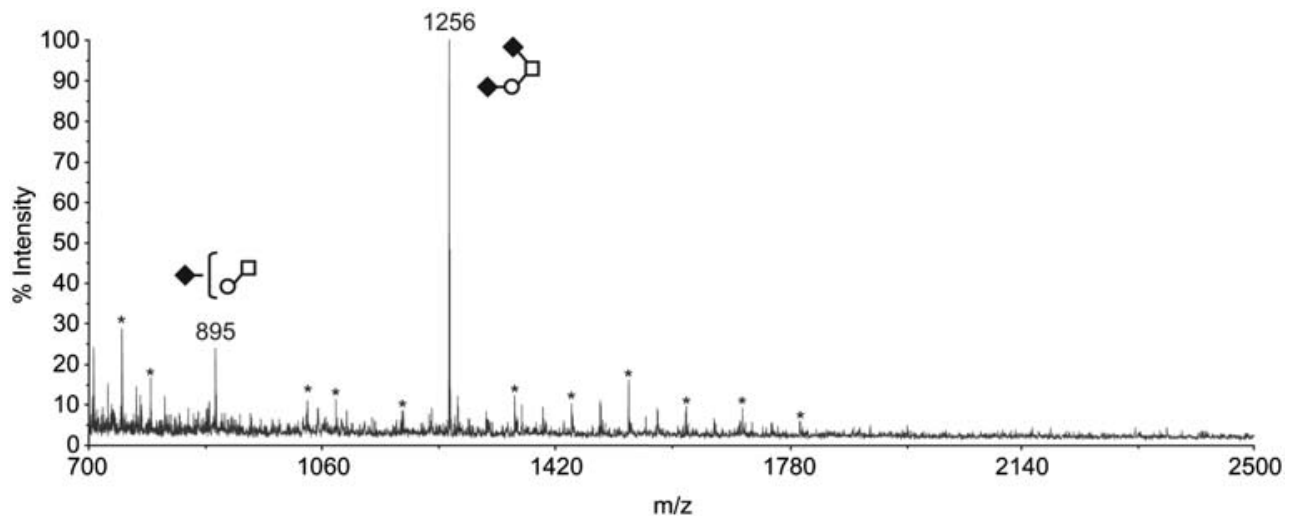

Figure 9 MALDI-TOF-MS spectrum of the permethylated O-glycans from brush border-enriched membranes.

After reductive elimination on de- $N$-glycosylated peptides, Dowex purification, and borate removal, O-glycans were permethylated, purified on a Sep-Pak C18, and analyzed by MALDI-TOF-MS. Symbols are as in Figure 3. 
A

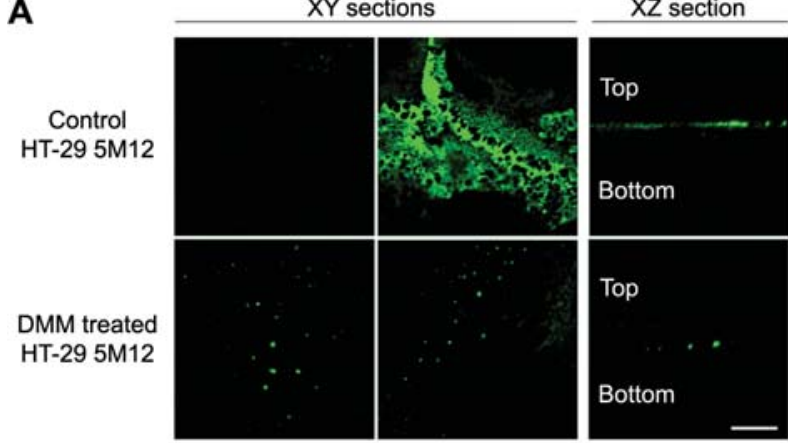

B

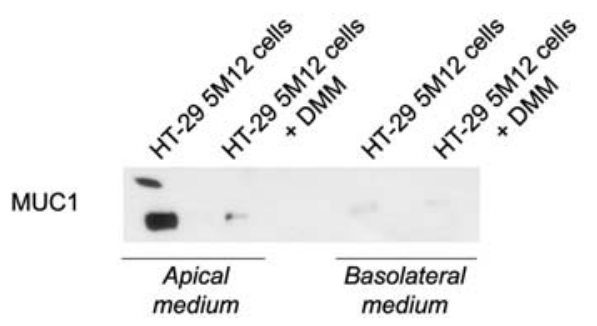

Figure 10 Analysis of the cellular distribution and extracellular release of MUC1 from 1-deoxymannojirimycin-treated HT-29 $5 \mathrm{M} 12$ cells using confocal microscopy (A) and Western blotting of apical cell culture media (B).

MUC1, which is localized at the brush border of control cells, was no more targeted to the apical surface but was retained intracellularly after treatment by 1-deoxymannojirimycin. MUC1 is no longer detected in the apical cell culture medium of 1deoxymannojirimycin-treated cells. Scale bar: $20 \mu \mathrm{m}$.

high mannose and complex type glycans with $N$-acetyllactosamine, with Lewis ${ }^{-x}$ and Lewis ${ }^{-y}$ antigenic determinants as major outer chains (Yamashita et al., 1987). CD-59 harbors a single $N$-glycosylation site and two potential O-glycosylation sites (Ninomiya et al., 1992). The structural analysis of the human erythrocyte CD-59 showed an extremely heterogeneous $N$-glycan pattern with more than 100 glycoforms, consisting mainly of biantennary glycans with varying numbers of $\mathrm{N}$-acetyllactosamine extensions and also of tri-antennary and tetra-antennary $N$-glycans (Rudd et al., 1997). The two $O$-glycosylation sites were found to be partially occupied with the O-glycans Neu5Ac $\alpha 2-3 \mathrm{Gal} \beta 1-3 \mathrm{GalNAc}$ and Gal $\beta 1-3[$ Neu5Ac $\alpha 2-6]$ GalNAc. MUC1 is a mucin-like transmembrane glycoprotein that contains five consensus sites for $\mathrm{N}$-glycosylation sites in a sequence adjacent to the transmembrane domain and a large ectodomain consisting of tandem repeats extensively $\mathrm{O}$-glycosylated (Gendler et al., 1991; Hilkens et al., 1992). The study of the $N$-glycosylation of a recombinant epitope-tagged MUC1 from enterocyte-like Caco-2 cells revealed a rather complex mixture of $N$-glycans with high mannose-, complex-, and hybrid-type structures (Parry et al., 2006). Several structural studies have investigated the O-glycosylation pattern of MUC1; however, different patterns were observed according to the cell type and the MUC1 molecular form (Lloyd et al., 1996; Burdick et al., 1997; Müller et al., 1997, 1999; Silverman et al., 2001, 2002, 2003; Müller and Hanisch, 2002; Engelmann et al., 2005). Membrane-bound MUC1 from T47D breast cancer cells was found to have a rather simple glycosylation pattern with NeuAc $\alpha 2-3$ Gal $\beta 1-3 G a l N A c-o l$, Gal $\beta 1-3 G a l N A c-o l$ and GalNAc-ol predominating (Lloyd et al., 1996). Structural studies carried out on secretory MUC1 glycoforms isolated from cell culture supernatants of different breast cancer cell lines showed that the $O$-glycosylation pattern was cell-specific with predominance of core 1- or core 2-based glycans (Müller and Hanisch, 2002). Interestingly, further studies comparing the O-glycosylation of membrane-bound or secretory recombinant MUC1 forms in MCF-7 cells revealed that the membrane-derived fusion proteins showed a shift from predominantly core 2 to nearly exclusive core 1 expression with $\mathrm{Neu}-$ Ac $\alpha 2-3 G a l \beta 1-3 G a I N A c$ predominating (Engelmann et al., 2005). Although our results cannot exclude the presence of minor $\mathrm{O}$-glycans other than the sialylated and bisialylated T-antigen structures, they suggest that these two structures are the predominant $O$-glycans in the brush border membrane of HT-29 5M12 cells.

Altogether, these data suggested that $N$-glycans rather than $\mathrm{O}$-glycans contained $\mathrm{N}$-acetyllactosamine motifs and were thus involved in the lipid raft-based galectin-4dependent apical delivery. In order to test this hypothesis, the distribution of MUC1 was analyzed in the presence of 1-deoxymannojirimycin, a drug which inhibits the processing of high mannose-type glycans into hybrid type or complex type glycans. Results showed that MUC1 substituted with high mannose-type glycans was not delivered to the apical brush border of HT-29 $5 \mathrm{M} 12$ cells and that the extracellular ectodomain of shed MUC1 was no more detected in the apical medium. Instead, MUC1 accumulated inside the cells. This observation indicates that complex type $\mathrm{N}$-glycans play a key role in the apical delivery of MUC1 in differentiated HT29 cells. However, these results do not exclude that $O$ glycans can also have a role in apical trafficking of membrane type and/or secretory mucins in HT-29 cells. Structural studies carried out on the mucus secreted by mucus-secreting HT-29 MTX cells showed the presence of $O$-glycans elongated by the addition of type 1 Galß1-3GlcNAc or type 2 Galß1-4GlcNAc N-acetyllactosamine units, although the sialyl T-antigen was found as the predominant structure (41\%) (Hennebicq-Reig et al., 1998). It must also be stressed that the presence of $O$-glycans is essential for cell surface expression of MUC1, as was shown by the rapid degradation of MUC1 in the absence of the addition of $O$-linked glycans to the mucin-like core of tandem repeats in Chinese hamster ovary cells (Altschuler et al., 2000).

Interestingly, we previously observed that 1-deoxymannojirimycin also perturbed the apical transport of the GPI-anchored glycoprotein CEA and of the transmembrane glycoprotein DPP-IV, but in contrast to MUC1, both CEA and DPP-IV were mistargeted to the basolateral membrane in the presence of 1-deoxymannojirimycin. This different behavior observed for MUC1 might be connected to the particular processing of the transmembrane MUC1 protein into the MUC1 heterodimeric complex. Indeed, soon after its biosynthesis, the transmembrane MUC1 protein undergoes a self-cleavage in the SEA domain which generates a large $\alpha$ subunit containing the $O$-glycosylated tandem repeats and a smaller $\beta$ subunit containing the membrane anchor and the cytoplasmic tail (Ligtenberg et al., 1992; Levitin et al., 2005). 
These two subunits remain tightly associated and MUC1 is expressed at the cell membrane as the $\alpha / \beta$ complex. Because the anti-MUC1 antibody used in our analyses is directed against an epitope localized in the ectodomain (Price et al., 1998), we cannot exclude the possibility that the cytoplasmic domain of MUC1, which contains binding sites for clathrin adaptor complexes, might be mistargeted to the basolateral membrane of HT-29 cells.

Altogether, our data reveal the crucial role of complex type $\mathrm{N}$-glycan in the galectin-4-dependent delivery of glycoproteins to the apical brush border membrane of enterocytic HT-29 cells. The pattern of $\mathrm{N}$-glycans of the brush border membrane glycoproteins was very heterogeneous, with the presence of high mannose- and hybrid type glycans as well as a multitude of complex type $\mathrm{N}$ glycans containing the $N$-acetyllactosamine recognition signals for the lipid raft-based galectin-4-dependent apical delivery. In contrast, the pattern of O-glycans was very simple with the presence of two major core type 1 O-glycans, sialylated and bisialylated T-antigen structures [Neu5Ac $\alpha 2-3 \mathrm{Gal} \beta 1-3 \mathrm{GalNAc-ol}$ and Neu5Ac $\alpha 2$ $-3 \mathrm{Gal} \beta 1-3(\mathrm{Neu} 5 \mathrm{Ac} \alpha 2-6) \mathrm{GalNAc}-\mathrm{Ol}$ ]. Thus, the presence of mature $\mathrm{N}$-glycans is a sugar-encoded signal for the galectin-4-dependent apical trafficking of MUC1 in enterocytic HT-29 cells.

\section{Materials and methods}

\section{Antibodies and lectins}

MAb directed against MUC1 (214D4) was a gift from J. Hilkens (The Netherlands Cancer Institute, Amsterdam, Netherlands). This antibody recognizes an epitope localized in the ectodomain (peptide PDTR) (Price et al., 1998). MAb directed against the Lewis $^{-x}$ antigen (ab3358) was purchased from Abcam (Cambridge, UK). TRITC-conjugated MAA (R-7801) was from EY Laboratories (San Mateo, CA, USA), rhodamine-labeled WGA $(R L-1022)$ and ConA (RL-1002) were purchased from Vector Laboratories (Burlingame, CA, USA).

\section{Cell culture}

Enterocyte-like HT-29 (clone 5M12) cells were cultured as previously described. For the analysis of the conditioned media by Western blot, control HT-29 5M12 cells were cultured in serumfree medium for $24 \mathrm{~h}$ and apical and basolateral media were collected and concentrated by 20 -fold on centricon 10. 1Deoxymannojirimycin was used at the concentration of $1 \mathrm{~mm}$ for $24 \mathrm{~h}$, in the presence of leupeptin $(100 \mu \mathrm{g} / \mathrm{ml})$.

\section{Purification of brush border-enriched membrane}

Enterocyte-like HT-29 5M12 cells were cultured as previously described up to day 10 and the purification of the brush border membrane was carried out using the protocol of Schmitz et al. (1973). After phosphate buffer saline (PBS) washings, cells were then sonicated in TM buffer (2 mM Tris/50 mM mannitol, $\mathrm{pH} 7.1$ with protease inhibitors). The clarified supernatant was then incubated with $2 \mathrm{~mm}$ of $\mathrm{CaCl}_{2}$ for $15 \mathrm{~min}$ at $4^{\circ} \mathrm{C}$, and the brush border-enriched membrane was obtained after ultracentrifugation (33 $500 \mathrm{~g}, 30 \mathrm{~min}$ ) in a 70.1Ti rotor (Beckman, Minneapolis, MN, USA) (Schmitz et al., 1973).

\section{Fluorescence microscopy}

Cells were processed as previously described using mAbs directed against MUC1 and Lewis ${ }^{-x}$ antigen. After PBS washings, cells were incubated for $2 \mathrm{~h}$ with secondary FITC-conjugated antibody. For labeling with fluorescent lectins, cells were incubated for $2 \mathrm{~h}$ with $40 \mu \mathrm{g} / \mathrm{ml}$ TRITC or rhodamine-conjugated probe. Laser microscopy analyses were performed using a Leica instrument (Model TCS-NT; Leica Microsystems, New York, NY, USA). Files of microphotographs were processed with Adobe Photoshop 5.0 (San José, CA, USA).

\section{Western blot analysis}

The cell culture media were processed as previously described (Gouyer et al., 2001). Detection was carried out by luminescence using the ECL Western blotting system (Amersham, Camarillo, CA, USA).

\section{Release of the $\mathbf{N}$-linked glycans after reduction and carboxyamidomethylation of glycoproteins and clean-up procedure of the released $\mathbf{N}$-glycans}

The brush border membrane glycoproteins were dissolved in $250 \mu \mathrm{l}$ of $600 \mathrm{~mm}$ Tris- $\mathrm{HCl} \mathrm{pH} 8.2$ and denatured by guanidine hydrochloride (6 $\mathrm{M}$ final concentration). The sample was incubated at $45^{\circ} \mathrm{C}$ for $1.5 \mathrm{~h}$. After addition of $500 \mu \mathrm{g}$ of dithiothreitol, the sample was flushed with argon and incubated at $45^{\circ} \mathrm{C}$ for $3 \mathrm{~h}$. After addition of $3 \mathrm{mg}$ of iodoacetamide, the sample was again flushed with argon and incubated at room temperature for $3 \mathrm{~h}$ in the dark. The sample was then dialyzed against $50 \mathrm{~mm}$ ammonium hydrogen carbonate at $4^{\circ} \mathrm{C}$ during $48 \mathrm{~h}$ and lyophilized. The reduced carboxyamidomethylated proteins were digested with L-1-tosylamide-2-phenylethylchloromethylketone (TPCK) bovine pancreas trypsin (EC 3.4.21.4, Sigma, Saint Quentin Fallavier, France) with an enzyme-to-substrate ratio of $1: 25$ (by mass), and the mixture was incubated for $24 \mathrm{~h}$ at $37^{\circ} \mathrm{C}$ in $50 \mathrm{~mm}$ ammonium hydrogen carbonate buffer. The reaction was terminated by boiling for $5 \mathrm{~min}$ before lyophilization. PNGase $\mathrm{F}$ digestion was carried out in ammonium hydrogen carbonate $50 \mathrm{~mm}$ for $16 \mathrm{~h}$ at $37^{\circ} \mathrm{C}$. After PNGase F digestion, the reaction was terminated by lyophilization and the products were purified on a C18 Sep-Pak to separate the released $\mathrm{N}$ glycans from the peptides. After conditioning, the C18 Sep-Pak by sequential washing with methanol $(5 \mathrm{ml})$, and $5 \%$ acetic acid $(10 \mathrm{ml})$, the sample was loaded onto the Sep-Pak and the $N$ glycans were eluted with $3 \mathrm{ml}$ of $5 \%$ acetic acid. Peptides/glycopeptides were eluted with $3 \mathrm{ml}$ of acetonitrile $(\mathrm{ACN}) /$ water $(80: 20 ; \mathrm{v} / \mathrm{v})$ containing $5 \% \mathrm{v} / \mathrm{v}$ acetic acid. ACN was evaporated under a stream of nitrogen and the samples were freeze-dried.

\section{Exoglycosidase digestions}

These were carried out on the released $\mathrm{N}$-glycans using the following enzymes and conditions: neuraminidase (from Vibrio cholerae, EC 3.2.1.18, Roche Molecular Biochemicals, Meylan, France): $50 \mathrm{mU}$ in $200 \mu \mathrm{l}$ of $50 \mathrm{~mm}$ ammonium formate buffer, $\mathrm{pH} 5.5$, for $48 \mathrm{~h}$; $\beta$-galactosidase (from bovine testes, EC 3.2.1.23, Sigma): $10 \mathrm{mU}$ in $200 \mu$ l of $50 \mathrm{~mm}$ ammonium formate, $\mathrm{pH} 4.6$, for $48 \mathrm{~h}$. All enzyme digestions were incubated at $37^{\circ} \mathrm{C}$ and terminated by boiling for $5 \mathrm{~min}$ before lyophilization. For sequential enzyme digestions, an appropriate aliquot was taken after each digestion and permethylated for MALDI-MS analysis after purification on a C18 Sep-Pak.

\section{Hydrogen fluoride treatment}

$\mathrm{N}$-Glycans were treated with $48 \% \mathrm{HF}$ (Aldrich, St. Quentin Fallavier, France) at $0^{\circ} \mathrm{C}$ for $20 \mathrm{~h}$ similar to the procedure 
described by Pang et al. (2007). After treatment, $\mathrm{N}$-glycans were permethylated.

\section{Permethylation and mass spectrometry analysis of glycans}

Permethylation of the freeze-dried $\mathrm{N}$-glycans was performed according to the procedure developed by Ciucanu and Kerek (1984). The reaction was terminated by adding $1 \mathrm{ml}$ of cold $10 \%$ $(\mathrm{v} / \mathrm{v})$ acetic acid followed by three extractions with $500 \mu \mathrm{l}$ of chloroform. The pooled chloroform phases $(1.5 \mathrm{ml})$ were then washed eight times with water. The methylated derivatives-containing chloroform phase was finally dried under a stream of nitrogen and the extracted products were further purified on a C18 Sep-Pak (Morelle and Michalski, 2007). The C18 Sep-Pak was sequentially conditioned with methanol $(5 \mathrm{ml})$, and water $(10 \mathrm{ml})$. The derivatized glycans dissolved in methanol were applied on the cartridge, washed with $3 \times 5 \mathrm{ml}$ water, $2 \mathrm{ml}$ of $10 \%(\mathrm{v} / \mathrm{v})$ acetonitrile in water and eluted with $3 \mathrm{ml}$ of $80 \%$ $(\mathrm{v} / \mathrm{v})$ acetonitrile in water. Acetonitrile was evaporated under a stream of nitrogen and the samples were freeze-dried. MALDITOF-MS and electrospray MS/MS analyses of permethylated glycans were performed as described elsewhere (Morelle and Michalski, 2007).

\section{Linkage analysis}

The permethylated $N$-glycans were hydrolyzed in $300 \mu \mathrm{l}$ of $4 \mathrm{M}$ trifluoroacetic acid (TFA) at $100^{\circ} \mathrm{C}$ for $4 \mathrm{~h}$. After removing TFA by drying in vacuo, the permethylated compounds were then reduced at room temperature overnight by adding $200 \mu \mathrm{l}$ of $2 \mathrm{M}$ ammonia solution containing sodium borodeuteride $(4 \mathrm{mg} / \mathrm{ml})$. The reduction was terminated by adding acetic acid and borates were eliminated under a stream of nitrogen in the presence of methanol containing $5 \%(\mathrm{v} / \mathrm{v})$ acetic acid. After adding $20 \mu \mathrm{l}$ of pyridine and $200 \mu \mathrm{l}$ of acetic anhydride, per-acetylation was carried out at $100^{\circ} \mathrm{C}$ for $2 \mathrm{~h}$. After evaporation under a stream of nitrogen, the partially methylated alditol acetates (PMAAs) were dissolved in chloroform and the chloroform phase was washed 10 times with water. This PMAA-containing phase was finally dried under a stream of nitrogen and the PMAAs were dissolved in methanol before GC-MS analysis. GC separation of PMAAs was performed using a Carbo Erba GC 8000 gas chromatograph fitted with a $25 \mathrm{~m} \times 0.32 \mathrm{~mm}$ CP-Sil5 CB Low bleed capillary column, $0.25 \mu \mathrm{m}$ film phase (Chrompack France, Les Ullis, France). The temperature of the Ross injector was $260^{\circ} \mathrm{C}$. Samples were analyzed using a temperature program starting by a gradient of $2^{\circ} \mathrm{C} / \mathrm{min}$ from $130^{\circ} \mathrm{C}$ to $180^{\circ} \mathrm{C}$, after $2 \mathrm{~min}$ at $130^{\circ} \mathrm{C}$, followed by a gradient of $4^{\circ} \mathrm{C} / \mathrm{min}$ until $240^{\circ} \mathrm{C}$. The column was coupled to a Finnigan Automass II mass spectrometer (Thermoquest, Les Ulis, France). Analyses were performed in the electron impact mode using ionization energy of $70 \mathrm{eV}$. Quantification of the various PMAA derivatives was carried out using total ion current of the MS detector in positive ion mode.

\section{Acknowledgments}

We thank Anne-Frédérique Dessein, Georges Grard, Marie-José Dejonghe and Hélène Fontayne for technical assistance. This work was supported by INSERM, CNRS, the Ministère de la Recherche et de l'Enseignement Supérieur and an EC Marie Curie Research Training Network grant (contract no. MCRTNCT-2005-19561). The Mass Spectrometry facility used in this study was funded by the European Community (FEDER), the Région Nord-Pas de Calais (France) and the Université des Sciences et Technologies de Lille I. Confocal microscopy was performed in the IFR114 IMPRT.

\section{References}

Alfalah, M., Jacob, R., and Naim, H.Y. (2002). Intestinal dipeptidyl-peptidase IV is efficiently sorted to the apical membrane through the concerted action of $\mathrm{N}$ - and $\mathrm{O}$-glycans as well as association with lipid microdomains. J. Biol. Chem. 277, 10683-10690.

Altschuler, Y., Kinlough, C.L., Poland, P.A., Bruns, J.B., Apodaca, G., Weisz, O.A., and Hughey, R.P. (2000). Clathrin-mediated endocytosis of MUC1 is modulated by its glycosylation states. Mol. Biol. Cell 11, 819-831.

André, S., Sansone, F., Kaltner, H., Casnati, A., Kopitz, J., Gabius, H.J., and Ungaro, R. (2008). Calix[n]arene-based glycoclusters: bioactivity of thiourea-linked galactose/lactose moieties as inhibitors of binding of medically relevant lectins to a glycoprotein and cell-surface glycoconjugates and selectivity among human adhesion/growth-regulatory galectins. ChemBioChem 9, 1649-1661.

André, S., Kožár, T., Kojima, S., Unverzagt, C., and Gabius, H.J. (2009). From structural to functional glycomics: core substitutions as molecular switches for shape and lectin affinity of $N$-glycans. Biol. Chem. 390, 557-565.

Benting, J.H., Rietveld, A.G., and Simons, K. (1999). N-glycans mediate the apical sorting of a GPI-anchored, raft-associated protein in Madin-Darby canine kidney cells. J. Cell Biol. 146, 313-320.

Brown, D.A. and Rose, J.K. (1992). Sorting of GPI-anchored proteins to glycolipid-enriched membrane subdomains during transport to the apical cell surface. Cell 68, 533-544.

Burdick, M., Harris, A., Reid, C., Iwamura, T., and Hollingsworth, M. (1997). Oligosaccharides expressed on MUC1 produced by pancreatic and colon tumor cell lines. J. Biol. Chem. 272, 24198-24202.

Ciucanu, I. and Kerek, F. (1984). A simple and rapid method for the permethylation of carbohydrates. Carbohydr. Res. 131, 209-217.

Dam, T.K., Gabius, H.J., André, S., Kaltner, H., Lensch, M., and Brewer, C.F. (2005). Galectins bind to the multivalent glycoprotein asialofetuin with enhanced affinities and a gradient of decreasing binding constants. Biochemistry 44, 1256412571.

Delacour, D., Gouyer, V., Zanetta, J.P., Drobecq, H., Leteurtre, E., Grard, G., Moreau-Hannedouche, O., Maes, E., Pons, A., André, S., et al. (2005). Galectin-4 and sulfatides in apical membrane trafficking in enterocyte-like cells. J. Cell Biol. $169,491-501$.

Delannoy, P., Kim, I., Emery, N., de Bolos, C., Verbert, A., Degand, P., and Huet, G. (1996). Benzyl- $N$-acetyl- $\alpha$-D-galactosaminide inhibits the sialylation and the secretion of mucins by a mucin secreting HT-29 cell subpopulation. Glycoconj. J. 13, 717-726.

Engelmann, K., Kinlough, C., Müller, S., Razawi, H., Baldus, S., Hughey, R., and Hanisch, F. (2005). Transmembrane and secreted MUC1 probes show trafficking-dependent changes in O-glycan core profiles. Glycobiology 15, 1111-1124.

Gabius, H.J. (2006). Cell surface glycans: the why and how of their functionality as biochemical signals in lectin-mediated information transfer. Crit. Rev. Immunol. 26, 43-79.

Gabius, H.J. (2008). Glycans: bioactive signals decoded by lectins. Biochem. Soc Trans. 36, 1491-1496.

Gabius, H.J., ed. (2009). The Sugar Code. Fundamentals of Glycosciences (Weinheim, Germany: Wiley- $\mathrm{VCH}$ ).

Gabius, H.J., Siebert, H.C., André, S., Jiménez-Barbero, J., and Rüdiger, H. (2004). Chemical biology of the sugar code. ChemBioChem 5, 740-764.

Gendler, S., Spicer, A., Lalani, E., Duhiq, T., Peat, N., Burchel, J., Pemberton, L., Boshel, M., and Taylor-Papadimitriou, J. (1991). Structure and biology of a carcinoma-associated mucin, MUC1. Am. Rev. Respir. Dis. 144, 42-47. 
Gouyer, V., Leteurtre, E., Delmotte, P., Steelant, W.F.A., Krzewinski-Recchi, M.A., Zanetta, J.P., Lesuffleur, T., Trugnan, G., Delannoy, P., and Huet, G. (2001). Differential effect of GalNAcalpha-O-bn on intracellular trafficking in enterocytic HT-29 and Caco-2 cells: correlation with the glycosyltransferase expression pattern. J. Cell Sci. 114, 1455-1471.

Gut, A., Kappeler, F., Hyka, N., Balda, M.S., Hauri, H.P., and Matter, K. (1998). Carbohydrate-mediated Golgi to cell surface transport and apical targeting of membrane proteins. EMBO J. 17, 1919-1929.

Haslam, S., Coles, G., Morris, H., and Dell, A. (2000). Structural characterization of the $\mathrm{N}$-glycans of Dictyocaulus viviparus: discovery of the Lewis ${ }^{\times}$structure in a nematode. Glycobiology 10, 223-229.

Hennebicq-Reig, S., Lesuffleur, T., Capon, C., de Bolos, C., Kim, I., Moreau, O., Richet, C., Hemon, B., Recchi, M., Maes, E., et al. (1998). Permanent exposure of mucin-secreting HT-29 cells to benzyl- $N$-acetyl- $\alpha$-D-galactosaminide induces abnormal $O$-glycosylation of mucins and inhibits constitutive and stimulated MUC5AC secretion. Biochem. J. 334, 283-295.

Hilkens, J., Ligtenberg, M., Vox, H., and Litvinov, S. (1992). Cell membrane-associated mucins and their adhesion-modulating property. Trends Biochem. Sci. 17, 359-363.

Huang, J., Byrd, J.C., Yoor, W.H., and Kim, Y.S. (1992). Effect of benzyl- $\alpha$-GalNAc, an inhibitor of mucin glycosylation, on cancer-associated antigens in colon cancer in human colon cancer cells. Oncol. Res. 4, 507-515.

Huet, G., Hennebicq-Reig, S., De Bolos, C., Ulloa, F., Lesuffleur, T., Barbat, A., Carrière, V., Kim, I., Real, F.X., Delannoy, P., et al. (1998). GalNAc-alpha-O-benzyl inhibits NeuAc $\alpha 2-3$ glycosylation and blocks the intracellular transport of apical glycoproteins and mucus in differentiated HT-29 cells. J. Cell Biol. 141, 1311-1322.

Ideo, H., Seko, A., Ohkura, T., Matta, K.L., and Yamashita, K. (2002). High-affinity binding of recombinant human galectin4 to $\mathrm{SO}_{3}{ }^{-} \rightarrow 3 \mathrm{Gal} \beta 1 \rightarrow 3$ GalNAc pyranoside. Glycobiology 12 , 199-208.

Ideo, H., Seko, A., and Yamashita, Y. (2005). Galectin-4 binds to sulfated glycosphingolipids and carcinoembryonic antigen in patches on the cell surface of human colon adenocarcinoma cells. J. Biol. Chem. 280, 4730-4737.

Jacob, R., Alfalah, M., Grünberg, J., Obendorf, M., and Naim, H.Y. (2000). Structural determinants required for apical sorting of an intestinal brush-border membrane protein. J. Biol. Chem. 275, 6566-6572.

Levitin, F., Stern, O., Weiss, M., Gil-Henn, C., Ziv, R., Prokocimer, Z., Smorodinsky, N., Rubinstein, D., and Wreschner, D. (2005). The MUC1 SEA module is a self-cleaving domain. J Biol. Chem. 280, 33374-33386.

Ligtenberg, M.J., Kruijshaar, L., Buijs, F., Van Meijer, M., Litvinov, S.V., and Hilkens, J. (1992). Cell-associated episialin is a complex containing two proteins derived from a common precursor. J. Biol. Chem. 267, 6171-6177.

Lloyd, K., Burchell, J., Kudryashov, V., Yin, B., and Taylor-Papadimitriou, J. (1996). Comparison of O-linked carbohydrate chains in MUC-1 mucin from normal breast epithelial cell lines and breast carcinoma cell lines. J. Biol. Chem. 271, 33325-33334.

Matter, K. and Mellman, I. (1994). Mechanisms of cell polarity: sorting and transport in epithelial cells. Curr. Opin. Cell Biol. $6,545-554$.

Morelle, W. and Michalski, J.C. (2007). Analysis of protein glycosylation by mass spectrometry. Nat. Prot. 2, 1585-1602.

Morelle, W., Faid, V., and Michalski, J.C. (2004). Structural analysis of permethylated oligosaccharides using electrospray ionization quadrupole time-of-flight tandem mass spectrometry and deutero-reduction. Rapid Commun. Mass Spectrom. 18, 2451-2464.

Mostov, K., Verges, M., and Altschuler, Y. (2000). Membrane traffic in polarized epithelial cells. Curr. Opin. Cell Biol. 12, 483-490.
Müller, S. and Hanisch, F. (2002). Recombinant MUC1 probe authentically reflects cell-specific O-glycosylation profiles of endogenous breast cancer mucin. High density and prevalent core 2-based glycosylation. J. Biol. Chem. 277, 26103-26112.

Müller, S., Goletz, S., Packer, N., Gooley, A., Lawson, A., and Hanisch, F. (1997). Localization of O-glycosylation sites on glycopeptide fragments from lactation-associated MUC1. All putative sites within the tandem repeat are glycosylation targets in vivo. J. Biol. Chem. 272, 24780-24793.

Müller, S., Alving, K., Peter-Katalinic, J., Zachara, N., Gooley, A., and Hanisch, F. (1999). High density O-glycosylation on tandem repeat peptide from secretory MUC1 of T47D breast cancer cells. J. Biol. Chem. 274, 18165-18172.

Naim, H., Joberty, G., Alfalah, M., and Jacob, R. (1999). Temporal association of the $\mathrm{N}$ - and $\mathrm{O}$-linked glycosylation events and their implication in the polarized sorting of intestinal brush border sucrase-isomaltase, aminopeptidase $\mathrm{N}$, and dipeptidyl peptidase IV. J. Biol. Chem. 274, 17961-17967.

Nakatsu, F. and Ohno, H. (2007). Adaptor protein complexes as the key regulators of protein sorting in the post-Golgi network. Cell Struct. Funct. 28, 419-429.

Ninomiya, H., Stewart, B., Rollins, S., Zhao, J., Bothwell, A., and Sims, P. (1992). Contribution of the $N$-linked carbohydrate of erythrocyte antigen CD59 to its complement-inhibitory activity. J. Biol. Chem. 267, 8404-8410.

Pang, S., Urquhart, P., and Hooper, N.M. (2004). N-glycans, not the GPI anchor, mediate the apical targeting of a naturally glycosylated, GPI-anchored protein in polarised epithelial cells. J. Cell Sci. 117, 5079-5086.

Pang, P., Tissot, B., Drobniz, E., Sutovsky, P., Morris, H., Clark, G., and Dell, A. (2007). Expression of bisecting type and Lewis ${ }^{\times} /$Lewis ${ }^{y}$ terminated $\mathrm{N}$-glycans on human sperm. J. Biol. Chem. 282, 36593-36602.

Parry, S., Hanisch, F., Leir, S., Sutton-Smith, M., Morris, H., Dell, A., and Harris, A. (2006). N-Glycosylation of the MUC1 mucin in epithelial cells and secretions. Glycobiology 16, 623-634.

Price, M.R., Rye, P.D., Petracou, E., Murray, A., Brady, K., Imai, S., Haga, S., Kiyozuka, Y., Schol, D., Meulenbroek, M.F.A., et al. (1998). Summary report on the ISOBM TD-4 workshop: analysis of 56 monoclonal antibodies against the MUC1 mucin. Tumor Biol. 19 (Suppl. 1), 1-20.

Rudd, P., Morgan, B., Wormald, D., Harvey, D., Van den Berq, C., Davis, S., Ferguson, M., and Dwek, R. (1997). The glycosylation of the complement regulatory protein, human erythrocyte CD59. J. Biol. Chem. 272, 7229-7244.

Scheiffele, P., Peranen, J., and Simons, K. (1995). N-glycans as apical sorting signals in epithelial cells. Nature 378, 96-98.

Schmitz, J., Preiser, H., Maestracci, D., Ghosh, B., Cerda, J., and Crane, R. (1973). Purification of the human intestinal brush border membrane. Biochem. Biophys. Acta 323, 98112

Schuck, S. and Simons, K. (2004). Polarized sorting in epithelial cells: raft clustering and the biogenesis of the apical membrane. J. Cell Sci. 117, 5955-5964.

Silverman, H., Parry, S., Sutton-Smith, M., Burdick, M., McDermott, K., Reid, C., Batra, S., Morris, H., Hollingsworth, M., Dell, A., et al. (2001). In vivo glycosylation of mucin tandem repeats. Glycobiology 11, 459-471.

Silverman, H., Sutton-Smith, M., Heal, P., Harris, A., Palmai-Pallag, T., Leir, S., Morris, H., Dell, A., and Hashidate, T. (2002). In vivo glycosylation of MUC1 in airway epithelial cells. Glycoconj. J. 19, 379-384.

Silverman, H., Sutton-Smith, M., McDermott, E., Heal, P., Leir, S., Morris, H., Hollingsworth, M., Dell, A., and Harris, A. (2003) The contribution of tandem repeat number to the Oglycosylation of mucins. Glycobiology 13, 265-277.

Simons, K. and Ikonen, I. (1997). Functional rafts in cell membranes. Nature 387, 569-572.

Simons, K. and Van Meer, G. (1988). Lipid sorting in epithelial cells. Biochemistry 27, 6197-6202. 
Stechly, L., Morelle, W., Dessein, A.F., André, S., Grard, G., Trinel, D., Dejonghe, M.J., Leteurtre, E., Drobecq, H., Trugnan, G., et al. (2009). Galectin-4-regulated of glycoproteins to the brush border membrane of enterocyte-like cells. Traffic 10, 438-450.

Vagin, O., Turdikulova, S., and Sachs, G. (2004). The H,K-ATPase $\beta$ subunit as a model to study the role of $N$-glycosylation in membrane trafficking and apical sorting. J. Biol. Chem. 279, 39026-39034.

Yamashita, K., Totani, K., Kuroki, M., Matsuoka, Y., Ueda, I., and Kobata, A. (1987). Structural studies of the carbohydrate moieties of carcinoembryonic antigens. Cancer Res. 47, 3451-3459.
Yeaman, C., Le Gall, A.H., Baldwin, A.N., Monlauzeur, L., Le Bivic, A., and Rodriguez-Boulan, E. (1997). The O-glycosylated stalk domain is required for apical sorting of neurotrophin receptors in polarized MDCK cells. J. Cell Biol. 139, 929-940.

Zanetta, J.P., Gouyer, V., Maes, E., Pons, A., Hemon, B., Zweibaum, A., Delannoy, P., and Huet, G. (2000). Massive in vitro synthesis of tagged oligosaccharides in 1-benzyl-2-acetamido-2-deoxy- $\alpha$-D-galactopyranoside treated HT-29 cells. Glycobiology 10, 565-575.

Received February 11, 2009; accepted April 3, 2009 